\title{
LÜKő István
}

\section{Mozaikok a szakképzés fejlődés közelmúlt évtizedeiből}

\author{
Az elsö Szakképzési törvénytöl napjainkig - Technológiaváltások, digitális pedagógia és hatásai
}

\section{Bevezető}

Mindig is fontos volt a szakképzés valamennyi szereplőjének a szempontjából, hogy a technikaitechnológiai fejlódés hatásait feltárják a szakképzés fejlesztése érdekében. Különösen napjainkban válik ez fontossá, érdekessé, mivel ez a fejlődés olyan mértékű és volumenű, hogy azt már nagyon nehéz követni és az oktatás, a szakképzés felé hatékony stratégiákat alkotni.

A nehézségek a személyes vállalásom szempontjából is jelen vannak, de ennek ellenére megkísérlem az elmúlt harminc-negyven év fontosabb társadalmi-gazdasági átalakulásait röviden ismertetni, hogy a szakképzés fejlődését kellő történelmi háttérrel megvilágítsuk.

Egyik célunk tehát az, hogy a rendszerváltástól napjainkig tartó korszak fontosabb eseményeit, jellemzőit bemutassuk és érzékeltessük ezek hatását az oktatásra, elsősorban a szakképzésre vonatkozóan. A kiemelkedő történelmi- politikai események mellett helyet kap a kormányzati politikák szempontjából és tudományos-szakmai szempontból is jelentős szerepet játszó oktatási rendszer átalakítása, illetve ennek állomásai, eseményei, többek között a törvényi szabályozások. Több évi előkészület után adták ki 1993-ban a három, oktatással foglalkozó törvényt, köztük a Szakképzési törvényt. Számos dokumentum, - mint pl. az OKJ - kapcsolódik a törvényhez, amelyeknek a kapcsolódásait és a más országokkal való összevetését vállaltam fel ebben az írásban. A törvény kiadásának 25. évfordulója alkalmából 2018. május 5.-én nagyszabású konferenciát szervezett a Magyar Pedagógiai Társaság és a BME Tanárképző Központja „25 éves a szakképzési törvény Korszakos változások - új irányok" címmel Budapesten, a BME-n.

Az oktatási törvényeknek számos előzménye volt, amit ugyancsak fontosnak tartok megemlíteni, s a későbbiekben részletesebben is bemutatni néhány fontos elemét, többek között az 1985-ös Oktatási törvényt.

Vizsgálódásom másik időbeli végpontja napjainkra esik. Vagyis a digitális átállás, az újra iparosítás (benne az újra automatizálás) korszakára, amely jócskán „kitermelte” az oktatás, a szakképzés szempontjából is központi kérdésként való igényét. Ennek a digitális pedagógiában kulminálódó szakmai és tudományos kérdéskörei képezik az írás másik fontos tartalmi témakörét és egyben a célját is.

Újfajta kihívással állunk szemben, amely a globalizáció révén egyszerre hat a jövő nemzedék nevelésétoktatását- képzését megvalósító rendszerekre, a mindennapi életünkre, és a munka, a termelés világára. Miközben a csúcstechnológia eszközei révén a robotizáció és az automatizáció egy negyedik ipari forradalom korszakába zárja az alkotó, tevékeny embert, sokszor nagyon is "öncélú", újabb globális problémákat generálnak a "fejlesztések, az innovációk”. Nem célunk ezeknek a tudomány filozófiai és etikai vetületeknek az érzékeltetése, de fontosnak tartottam így a bevezetőben megemlíteni ezt a sajátos életérzést.

Nehéz volt mindig is megragadni a technológiaváltások markáns jellemzőinek és az oktatás, a szakképzés változásai közötti összefüggéseket, de napjainkban különösen az. Ennek ellenére megkísérlem a technológiaváltások fontosabb szakaszait jellemezni és párhuzamosan a szakképzés fejlődési fázisait hozzárendelni. Ez biztosan nem fog teljes képet kirajzolni, tehát ezért is indokolt a „mozaikok" megjelölés már a címben is. Másrészt mozaikos ez a bemutatás a nagyon különböző területek és kutatási módszerek miatt is, valamint a kutatás-vizsgálódás mélysége miatt is. 
Egy negyedik cél az, hogy a szakképzési változásokat nemzetközi kontextusban mutassam be. Ezt eddig a témával foglalkozó előadásaim, prezentációim és publikációim során a mozaikos alcímként is kiemeltem. Az elsődleges és másodlagos források nagy mennyiségű adatai, tényei és elemzései ellenére a sajátos szemléletem és előéletem meghatározza a tartalmi területeket, az összefüggések megláttatását. Noha jómagam is végeztem önállóan, kutatói teamban itthon és külföldön is összehasonlító nemzetközi kutatásokat (Lükő 1999, Lükő 2004, Lükő 2005), tehát ezekre tudtam építkezni, mégis meg kell említenem számos más múhelyből és forrásból származó meghatározóan fontos és értékes munkákat.

Mindenek előtt a vizsgált időszakot felező évben, vagyis 2007-ben kiadott projekt összefoglalót, amelyet Benedek András írt(Benedek, A., 2007). Az NSZFI-ben megjelent 187 oldalnyi anyagban egy széleskörű, nagyon sokféle szervezetet képviselő hazai kutató-fejlesztő gárda munkájáról olvashatunk. A Nemzetközi összehasonlító elemzés a szakképzésben című kiadvány az adott korszaknak a teljes keresztmetszetében (integráltságában) mutatja be a szakképzés fejleszthetőségével kapcsolatos kutatási eredményeket, modelleket, adatokat és tényeket.

Különösen értékesnek tartom azt a kutatási nemzetközi hátteret bemutató részt, amelyben a háttérinformációk feldolgozásához nélkülözhetetlen webes felületről írnak, azt a Webtérképet, amelyben a Dokumentumtár a következő struktúrájú volt(Benedek, 2007. 16-22. o): Európai Unió, Nemzetközi szervezetek, Hazai szervezetek, Statisztikák, adatbázisok, Definíciók, Országjellemzők. Az Európai szervezeteken belül is külön részben voltak összegyújtve a szervezetek, és külön a programok az elérhető linkekkel és néhány mondatos szakszerú leírással. Előbbiek között ma is nagy szerepet és hasznos felületet jelentő szervezetek találhatók, mint pl.: CEDEFOP, European Training Village, European Training Foundation, Association Teacher Education in Europe(ATEE). Az európai szakképzési programok és kezdeményezések területéről pedig: EUROPASS, Lifelong Learning Programme 20072013, EQF, TEMPUS emelhető ki abból a szempontból is, hogy ezeknek a szerepe, illetve információ tartalma és alkalmazása, máig kihatással bír. Ugyancsak figyelemre méltó információkat tartalmaz az egyes országok szakképzési rendszeréről szóló gyűjtemény, mert 21 ország,- köztük más kontinens országai is,- oktatási rendszerhez való illeszkedését, a szakképzés fontosabb jellemzőit és az irányításban szerepet játszó minisztériumok elnevezését is megtaláljuk és elemezhetjük.

Számos részletét, elemét és különlegességét is kiemelhetném még ennek a 46 ív terjedelmű beszámolókból összeállított könyvnek, de csak azt a fontos,- ma is változatlanul, ső́t most különösen,megállapítást idézem: „A szakképzési rendszer fejlődése szervesen összefügg a tanárképzés minöségével." (Benedek, 2007 id. mü, 54. oldal.)

\section{A téma behatárolása, a vizsgálódás dimenziói}

A behatárolás egyikét már a bevezetőben érintettem, vagyis az elmúlt 30 év változásait vizsgálom. Másik behatárolás a tartalmi területek, pontosabban a fókuszpontok. A szakképzés nagyon összetett, bonyolult rendszer, ezért a valós helyzet feltárása számos módszerkombinációt igényel. A szakképzés egy többdimenziós szervezeti- tartalmi elemekkel, és szereplők kapcsolatrendszerével jellemezhető. Ezeket egy sajátos ábrázolási módon mutatom be az alábbiakban. 


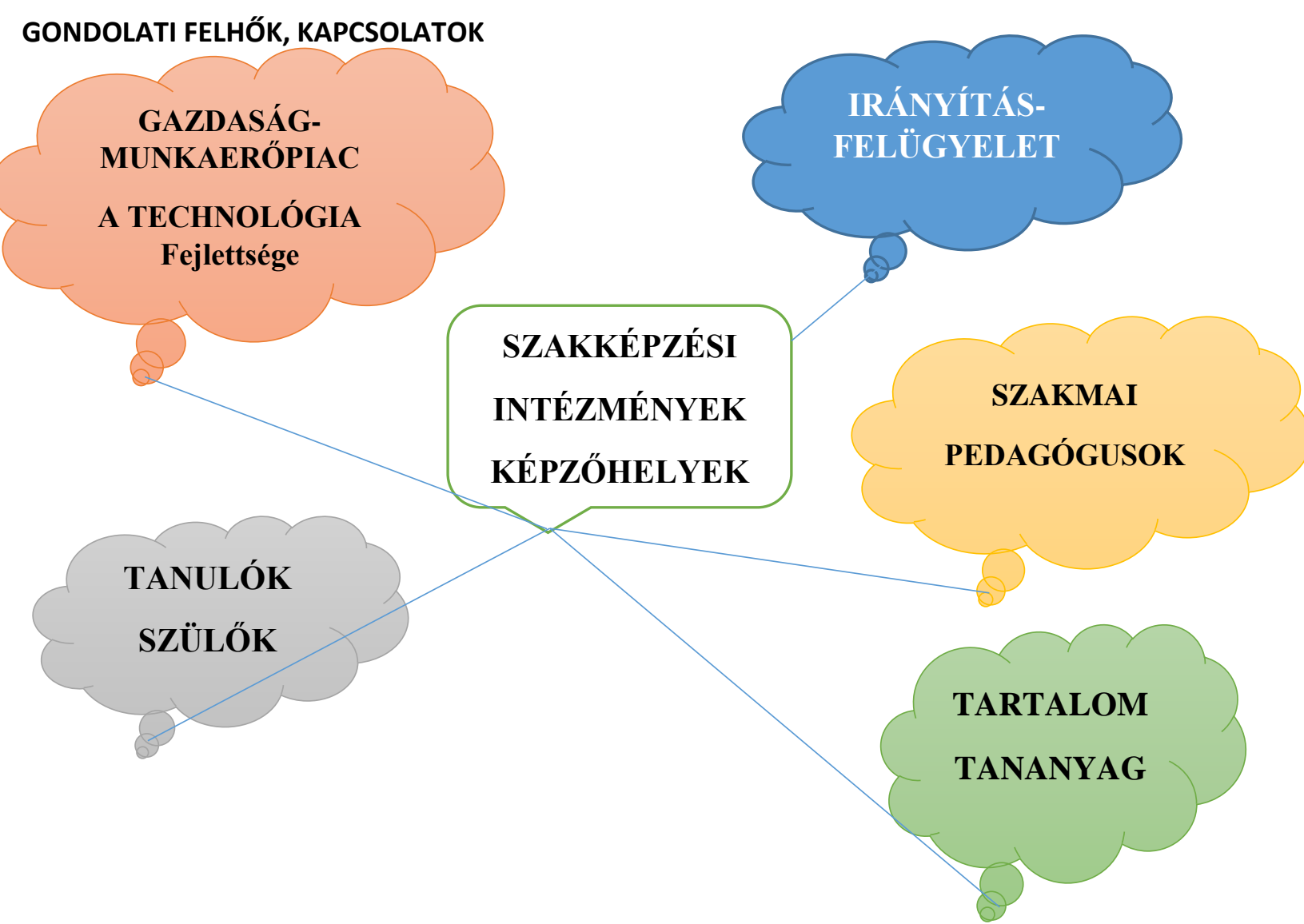

Forrás: Saját ábra

Ebből a kapcsolatrendszerből, vagy másképpen a szereplőkből kiindulva lehet levezetni a kihívásokat, illetve a hazai rendszerre jellemző problémákat. Leginkább itt érzékelhető, hogy a szakképzés szereplői közül nem tudjuk mindegyiket egyforma mélységgel és terjedelemben vizsgálni, feltárni.

Témánk szempontjából a fókuszálásunk a rendszerváltás idején megvalósuló törvényi szabályozásra, annak körülményeire, előzményeire, az egyik civil szakmai szervezetre, a Magyar Szakképzési Társaság megalakulására koncentrál elsősorban. Másodsorban az utolsó 10 év technológiai váltás fontosabb jellemzőire, a digitális pedagógia szakképzésben betöltött szerepére fókuszál.

\section{A vizsgált történeti szakasz elötti korszak helyzetröl vázlatosan}

Úgy érzem, hogy a kontinentális integráció, mint szakképzést is befolyásoló szemlélet egy távolabbi időpontról való megközelítése is hasznos lehet. Ezt pedig Csákó Mihály tanulmányai és 2016-ban megjelent cikke alapján merem megtenni, természetesen csak vázlatosan. A történeti kitekintést nyújtó cikkből kirajzolódik a szakképzéspolitika dominanciaváltásainak jellegzetes korszakai, eseményei, egy fontos kutató-fejlesztő szervezet létrejötte, az általános és a szakképzés viszonyának megváltozása stb.

Csákó Mihály A szakképzés és az európai integráció címmel írt cikket az Educatio 2016/1. számában.(Csákó, 2016) Két érv, vagyis, a szakképzettségek kölcsönös elfogadtatásának, valamint a munkások fizetésének a javítás játszott szerepet az Európai Unió elődjét, az Európai Gazdasági Közösséget (EGK, angol rövidítése: EEC) megalkotó Római Szerződésben is, 1957-ben.

A hatvanas években még a mezőgazdaság dominált számos európai országban, túltermelés, konkurencia lépett fel és a modernizáció, a technológiai váltás következtében az ágazatban 
foglalkoztatottak száma drasztikusan csökkent, nagymértékben nőtt a munkanélküliség ebben az ágazatban „A szakképzés számára természetesen nem a mezőgazdaság gondjai érdekesek, hanem az abból kiszorulóké: a mezőgazdasági népesség csökkenése átképzési szükségletet kelt és a szakképzés átalakitását is szükségessé teszi." (Csákó, id. mü 14. oldal)

Az általános elvekben megfogalmazták, hogy mit is jelent a közös politika, ami a programok összefogását és a fokozatos, közös összefüggő intézkedéseket jelentette. Erős felhatalmazás helyett a Bizottság információs és kommunikációs feladatok sorát kapta (a 4. elv keretében), ezek közül most csak az egyiket emelem ki.

- a szakképzés kutatása és tanulmányozása a foglalkoztatás és a munkások szakmai és földrajzi mobilitása érdekében;

1972-ben az EGK párizsi csúcsértekezletén az állam- és kormányfők úgy döntöttek, hogy határozottabb intézkedéseket kell tenni a szociális problémák megoldására. Ekkor javasolták a Szakoktatási és képzési Központ, közismert rövidítéssel: a Cedefop felállítását.

\section{A 80-as-90-es évek szákképzéspolitikája}

Csákó Mihály szerint: „az olajválság ifjúsági munkanélküliség, kiindulópontját képezte Jacques Delors nyolcvanas évekbeli szélesebb programjának, amely a szociális Európa megteremtését tüzte ki célul (Az Európai Közösségeket egyesítő Maastrichti Szerződésben (1992) láthatjuk egy szemléletváltás első jelét. A Római Szerződés III. részében a III. cím címe helyett ezt iktatták be: VIII. cím: Szociálpolitika, oktatás, szakképzés és ifjúság

A szakképzést mindig az általános képzéssel szemben szokták meghatározni, és ez a két terület a XX. század nagy részében teljesen különállónak számított. A fentebb leírt folyamatok közepette azonban olyan jelentős változások mentek végbe a technológiában, amelyek megváltoztatták a szakképzés feltételeit. Bár az élethosszig tanulás korai megfogalmazásai már a hatvanas évektöl jelen voltak a pedagógiai kiadványokban, és a „vocational training”-ből eközben „vocational education and training (VET)" lett, csak a kilencvenes években vált annyira kiáltóvá a szakképzés elökészitő tudásszükséglete, hogy többé nem lehetett külön területként kezelni az általános és a szakképzést". (Csákó M., 2016. )

\section{A korszak gazdasági-társadalmi jellemzői}

Politikai-társadalmi események

Az 1980-as-90-es évek kontinensen túlmutató társadalmi-politikai eseményekben bővelkedett. Érdemes kitérni rá, mert a hazai eseményeket, gazdaságot és a szakképzést is formáló erővé váltak. A Szovjetunió az 1990-91 között zajló tagországok kiválásával megszűnt. Ennek politikai erőformáló hatása máig kihat bizonyos tekintetben. A soproni határnyitást követően 1989. november 4-én lebontották a berlini falat, mint az egykori fővárost és Németországot kettészelő határvédelmirendszert. Újra egyesül Németország 1990. október 3.-án.

Déli szomszédunk, Jugoszlávia is felbomlott, itt az országok zömében 1989-90-ben váltak ki. Nem sokkal ezután kitört a balkáni háború, amely nagy gazdasági és társadalmi károkat okozott.

Számos országban zajlott a politikai rendszerváltozást jelképező demokratizálódás felé elmozdító „bársonyos forradalom”, többpártrendszer jött létre hazánkban is. Az első szabad választások után megalakulnak Közép-Kelet-Európa országaiban a koalíciós kormányok.

Gazdasági-társadalmi változások és következményei

A 80-as-90-es években még nem létezett az Európai Unió, ezért más gazdasági közösségeket tudunk megemlíteni, illetve a különböző összehasonlításokhoz számításba venni. Az OECD mint globális szervezet mellett Európában az EFTA és az EK fogta össze a különböző érdekek, gazdasági prioritásokmenti tevékenységeket. A politikai-társadalmi rendszerváltás hazai gazdasági következményei közül a privatizációt kell kiemelni, amely a főként anyag és energiaigényes ágazatok 
nagyvállalatainak megszúnését, illetve magántulajdonba kerülését jelentette elsősorban. A nehézipar, a gépi nagyipar radikális visszaszorulása, más szektorok, illetve ágazatok megjelenése, bővülése igen jelentős munkaerő át struktúrálódással járt. Drámaian nőtt a munkanélküliség. A foglalkoztatottak 4,5 milliós létszáma évek alatt 3,5-3,6 millióra csökkent, 1989-92 között 1.174.000 munkahely szűnt meg. Ezeket az adatokat láthatjuk az 1. sz táblázatban

1. sz. táblázat: A munkanélküliség alakulása a 90-es évek elején

\begin{tabular}{|l|l|l|l|}
\hline Évek & 1991 & 1992 & 1993 \\
\hline Munkanélküliek száma & 406124 & 663022 & 632050 \\
\hline
\end{tabular}

Forrás: saját szerkesztés

Nemzetközi kitekintésünkben a kontinens néhány országában vizsgáltuk a GDP, a foglalkoztatottak számának, valamint a munkanélküliségnek az alakulását két időmetszetben.

2. sz. táblázat: Nemzetközi kitekintés a GDP, a foglalkoztatottság és a munkanélküliség területéről

\begin{tabular}{|c|c|c|c|c|c|c|}
\hline \multirow[t]{2}{*}{ Országok } & \multicolumn{2}{|c|}{ GDP PPP USD } & \multicolumn{2}{|c|}{$\begin{array}{l}\text { Foglalkoztatottak } \\
\text { száma ezer Fő }\end{array}$} & \multicolumn{2}{|c|}{ Munkanélküliség \% } \\
\hline & $1988-93$ & 2016-2017 & $\begin{array}{l}1988- \\
93\end{array}$ & 2016-2017 & $1988-93$ & 2016-2017 \\
\hline Magyarország & 8802,63 & 24163,91 & na & $4,516.93$ & 0,463 & 4.4 \\
\hline Bulgária & 7248.50 & 18787.44 & na & 3.525 .35 & na. & 6.6 \\
\hline Csehszlovákia & na & $\begin{array}{l}\text { Szl } 31026 \\
\text { Cs } 34541\end{array}$ & na & Szl 2,372 & 19954.00 & $\begin{array}{l}\text { Szl.8.1, } \\
\text { Cs.2,8 }\end{array}$ \\
\hline Lengyelország & 9081,5 & 26636,14 & na & 16,281 & $1990: 6,30$ & 4.8 \\
\hline Románia & 5874,82 & 16901,54 & na & $8,668.20$ & 3.700 & 5,3 \\
\hline Ausztria & 16537 & 49962,09 & 2.810 & 4.412 .54 & 2,676 & 5.4 \\
\hline Németország & 15929,27 & 45236,65 & 36.48 & 44,291 & 7.735 & 3.8 \\
\hline Franciao. & 15916,12 & 41146.65 & 22.30 & $27,901.1$ & 10.01 & 9.5 \\
\hline Görögország & 11828.94 & 30730.53 & 3.806 & 4.170 .49 & 7.423 & 22.3 \\
\hline Hollandia & 16324.64 & 49002.40 & 6.093 & 9.099 & 6,247 & 5.1 \\
\hline Olaszország & 15167.29 & 33274,41 & 20.98 & $25,105.50$ & 9.683 & 11.4 \\
\hline Írország & 11032.73 & 51513.45 & 1.111 & 2,084 & 16.30 & 6.4 \\
\hline
\end{tabular}

Forrás: saját szerkesztés

\section{A német újra-egyesítés és tervezési vonatkozásai}

Kuriózumként kezelem azt a forrást, amely bizonyítja, hogy a két német állam (NDK, NSZK) egyesítése előtt a szakképzés és foglalkoztatás kutatásával is foglalkozó háttérintézményben (IAB) készítettek tanulmányokat, amelyben prognosztizálták a keletnémet területek egyesülés utáni foglalkoztatási 
munkanélküliségi helyzetét iparáganként nagy területi felbontás szerint. Ebből kiindulva tervezték a húzó ágazatok kvalifikációs és munkaerő igényét, szakképzési vonzatát. Magáról a tervezés módszertanáról nem adtak információt, de sikerült egy dokumentumot a 1990-es freiburgi tanulmányutamon megszerezni. (Dieter Blaschke, Martin Koller, Gerhard Kühlewind (1990): Qualifizierung in den neuen Bundesländern IAB Nr. 7/1990) Három ágazat (mezőgazdaság és erdészet, textilipar, nehézipar (szénbányászat, vegyipar, fémipar, energiaipar,)) regionális súlypontjait ábrázolja az alanti ábra az új szövetségi államban.

2. ábra: Részletek a német munkanélküliségi és ágazati fejlesztési tervekből

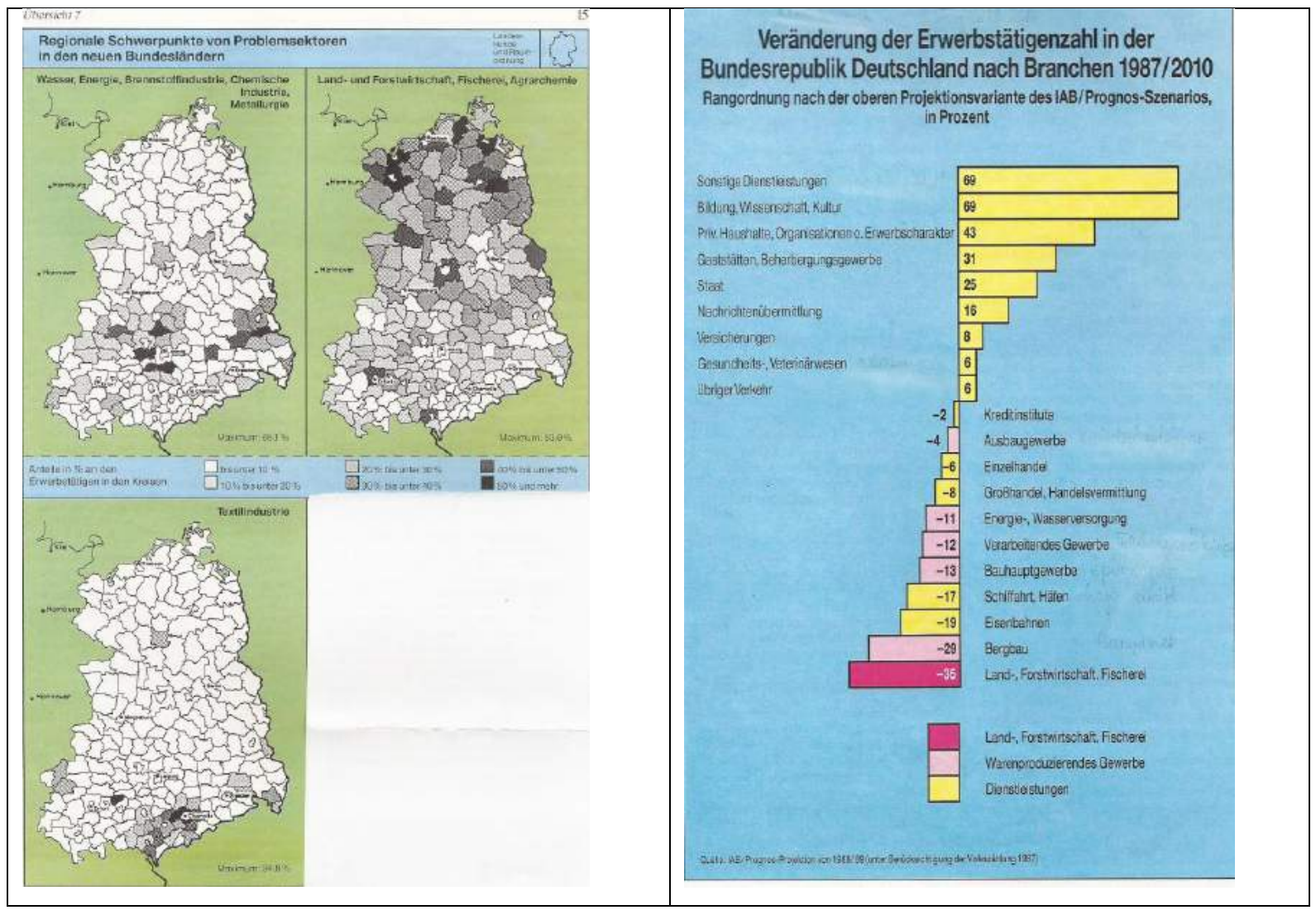

Forrás: IAAB 1990/7

Amint a bal oldali ábrán nagyon jól kirajzolódik, az annak a kutatásmódszertani precízségnek a „terméke”, amivel szinte négyzetkilométernyi pontossággal ábrázolták az egyes szektorok/ágazatok regionális megoszlását, mint súlyponti problémákat. A másik különlegessége ennek a dokumentumnak az, hogy a német egyesítés előtti évben készült, vagyis „tudatosan készültek az egyesülés utáni foglalkoztatási, szakképzési problémák kezelésére.

\section{Az első szakképzési törvény és az OKJ}

\section{Elözmények}

Nem csak a hazai viszonyokat érintően, hanem a demokratizálódási folyamatok jegyében nemzetközileg is meghatározó volt az 1985-ben kiadott I. Oktatási Törvény, amely még mind a három oktatási alrendszert, vagyis a közoktatást, a szakképzést és a felsőoktatást egységes keretben szabályozta a legmagasabb jogi formátumban. A Gazsó Ferenc nevéhez kötődő törvény a puha diktatórikus társadalmi rendszer és a demokratikus korszak közötti átmenetben született. Számos elemével előkészítette a rendszerváltás utáni decentralizált oktatási átalakításokat. Többek között a közvetlen igazgatóválasztás, az igazgatók munkáltatói, gazdálkodási jogkörének, az alternatív tantervek bevezetésével modellt alkotott. 
Ha összehasonlítjuk napjaink oktatási törvénykezéseivel, akkor megállapítható, hogy a decentralizáció szinte megszűnt, erős centralizáció érvényesül az oktatás mindhárom alrendszerének az irányításában.

\section{Az adaptív szakképzési modell és jellemzői}

Azért tartom fontosnak kitérni erre ebben a cikkben, mert jól bizonyítja, hogy az első szakképzési törvény előtt már léteztek makroszinten tudományosan megalapozott modellek, amelyek a szakképzés és a gazdaság „közelítését” célozták meg. A nyolcvanas évek közepe után az OPI Szakképzési Igazgatóságának munkatársai Benedek András irányításával egy átfogó modellt dolgoztak ki, amelyben a fejlesztés súlypontjait (tankönyv vizsgálat és kutatás, tantervfejlesztés, módszertani fejlesztés, oktatásszociológiai vizsgálatok stb.) a gazdaság szakemberigényeihez igazították. (Benedek, 1987)

Az adaptív szakképzés kísérleti terepei a vendéglátás, az energetika és a gépészet területét érintették és számos nagyvállalat vett benne részt, mint pl. a Ganz Mávag, a Paksi Atomerőmű, valamint a HungarHotels Lőver Szálloda

Ez utóbbit ismertem meg közelebbről és a szakmai-tudományos eredmények méltatását egy itt tanító történelem tanár, Horváth Edit által írt „Történelem tankönyv” felmutatásával illusztráltam az emlékkonferencia előadásomban, ami a kollégák lelkesedését, motivációját is bizonyította.

\section{Az MSZT megalakulása, és a remény, az összetartozás érzése}

Amikor 1989 októberében megalakult a BME K épületében a Magyar Szakképzési Társaság (MSZT), akkor mindnyájan szinte eufórikus hangulatban voltunk, teli reményekkel, tettrekészséggel, az összetartozás fontos és motiváló érzésével csatlakoztunk ehhez a szervezethez, amely 2013-ig önállóan múködött és tevékenykedett.

A megalakulás időszakában meghatározóan fontos események kapcsolódtak ehhez a szervezethez is, mint pl. az Nemzeti Szakképzési Intézet megalakulása az OPI Szakképzési Igazgatósága bázisán, a széleskörű egyeztetési hálózat kialakulása (MNGYSZ, MKIK, IPOSZ, MPT stb.) Sorban alakultak meg a regionális munkaerőfejlesztő és képző központok (RMKK--k) 1992-tôl. Az alapszabály nagyszerü iránytü és keret volt, amelynek a módositásai mindig követték a szervezet célkitüzéseinek a változásait. Az Alapszabály egy részének bemutatásával illusztrálom a tevékenység keretét meghatározó gondolatokat, célokat.

3. ábra: Az MSZT Alapszabály részlete 1998-ból

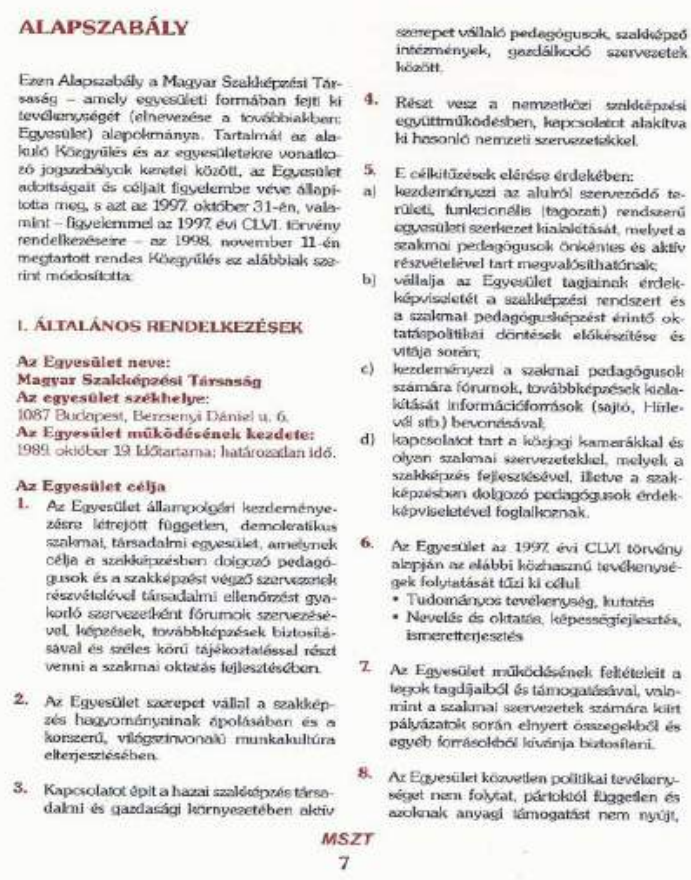


A társaság gazdag kapcsolatrendszerben 24 tagozattal, határon túli és külföldi szervezettel együttmúködve fejtette ki a tevékenységét. Hogy csak a legjelentősebb szervezeteket, programokat soroljuk fel: PHARE, QFERBAND,BIBB stb. Az individuális és a szervezeti szempontból is nagyon fontos, motiváló, innovációt gerjesztő volt a tanulók és a szakmai pedagógusok külföldi tapasztalatszerzése, illetve ennek a szervezése, gondozása. Sokan éltük meg a fejlettebb országok szakképzési rendszerének, múködésének tanulmányozása során ezeket a gazdagító, látókört, mi több gondolkodást és cselekvést is formáló élményeket.

A társaság részt vett számos nagyobb jelentőségű oktatási képzési dokumentum (NAT, OKJ Szakképzési Törvény, Felsőoktatási Törvény stb.) véleményezésében. Kritikai észrevételei eleinte szinte majdnem teljesen beépültek, majd egy idő után teljesen háttérbe szorult ez a véleményformálás. Nem volt igény az efféle társadalmi egyeztetési fórumot is képviselő megnyilvánulásra. Ennek hátterében számos tényező volt, de az egyértelműen kitapintható volt, hogy a MKIK szakképzési térnyerése már-már túlsúlyossá vált. Ez a helyzetkép mára már oldódott, illetve csökkent és számos jele, szervezeti megnyilvánulás igazolja ezt.

\section{Megszületnek a törvények és az OKJ}

Az elökészületek

A rendszerváltás első kormányzati ciklusában három oktatással foglalkozó törvényt adtak ki. Az elökészületek egyik részében tehát ezen törvények koncepcionális körvonalait, kapcsolódásukat járták körbe különböző szinteken.

A törvény elökészítése több hónapon keresztül tartó alapos egyeztetések, véleményezések széles körében zajlott számos meghatározóan fontos társadalmi, civil és szakmai szervezet bevonásával. (MPT, MSZT, MNGYSZ, MKIK, IPOSZ). Nem csak a szakképzési törvényt, hanem a kapcsolódó OKJ-t is hasonló körültekintő, a tripartit elv alkalmazásával (munkaadók, munkavállalók, állam) készítették elő.

\section{Az első szakképzési törvény fontosabb jellemzői}

Az 1993. évi LXXVI. törvény a szakképzésröl címet viselő legmagasabb szintű jogszabály átfogóan, az akkori korszak gazdasági képzésében érintett szervezetekre kiterjedően a legutóbbi módositott változathoz képest sokkal kisebb terjedelemben jelent meg. Érvényesült benne a tripartit elv, konszenzuson alapult és szakmai-pedagógiai szempontból is példaértékü volt. Számos tanulói és pedagógusi jogot és kötelezettséget megnyugtatóan és korrekt módon biztosított. Az egyik fontos jellemzője, - ami máig megmaradt -, hogy az első szakma megszerzése ingyenes. Rögzitette, hogy a szakképzés irányitásának háttérintézményeként létre kell hozni a kutatás-fejlesztés, a tankönyvellátás, a tartalmi szabályozás és más feladatok ellátására egy központi szervezetet, a Nemzeti Szakképzési Intézetet. Sajnos ez mára hivatallá alakult, számos feladat elkerült onnan és kutatásról már egyáltalán nem lehet beszélni, csak az egyetemeken találkozhatunk ezzel a tevékenységgel.(Lükö, 2018)

A fent idézett publikációban táblázatokkal illusztráltam a törvény hatályossági területeit, valamint a kapcsolódó rendleteket, mint pl. az OKJ, a gyakorlati képzés feltételrendszere, a tanulói juttatások rendszere stb.

\section{Nemzetközi kitekintés a szakképzés törvényi szabályozásáról}

Vizsgálódásaim során összegyújtöttem azokat az információkat, amelyek az egyes országok szakképzési rendszerének a törvénykezési formáit rögzítik.

Egy egyszerű táblázatban foglaltam össze ezeket. 
3. táblázat: A szakképzés törvényi szabályozása néhány országban

\begin{tabular}{|c|c|c|}
\hline Ország & Törvényi szintű szabályozás & $\begin{array}{l}\text { Más szintű szabályozás (Miniszteri } \\
\text { rendelet) }\end{array}$ \\
\hline Románia & NEM & IGEN, KORMÁNYR. MINR. \\
\hline Szlovákia*** & NEM, 2006-TÓL IGEN & \\
\hline Ukrajna & NEM & \\
\hline Szerbia* & & IGEN \\
\hline Ausztria & IGEN & \\
\hline Szlovénia* & NEM, 1996-TÓL & \\
\hline Magyarország & IGEN & \\
\hline Csehország*** & NEM, 2006-TÓL & \\
\hline Németország & IGEN & \\
\hline Franciaország & IGEN & \\
\hline UK & NEM $* * * *$ & IGEN> \\
\hline USA & NEM & \\
\hline Oroszország & NEM & IGEN, MIN R. \\
\hline Csehszlovákia*** & NEM, & \\
\hline Szovjetunió ${ }^{* *}$ & NEM & \\
\hline
\end{tabular}

\section{A technika-technológiai fejlődés és szakaszai, jellemzői}

Már az eddigiekben is nagyon részlegesen és halványan megjelentek a technikai fejlődés korszakos jellemzői, hatásai, de ebben a fejezetben szisztematikusan fogjuk ezt feltárni, illetve bemutatni. Számos aspektusból lehet ezt a témát is megközelíteni, azonban mi egy komplex szemlélettel tesszük ezt, elsősorban a szakképzés-pedagógia, a technikaszociológia, a digitális pedagógia és számos más határtudomány módszertana segítségével.

A 30 éves korszak nem képez ugyan jelentős neveléstörténeti-oktatástörténeti léptéket, mégis egyfajta történeti szemléletmódot is közvetítünk.

\section{Az alapfogalmak (technika, technológia, intelligens technológia)}

Általában mondhatjuk azt, hogy a műszaki tudományok technika fogalmát szúkebb értelemben használják, mint a szociológiában illetve a pedagógiában. A mérnökök, a műszakiak technikán elsősorban gépeket, műszereket, felszereléseket stb. értenek, a szociológusok a gondolkodás, a kutatás, a nevelés, az oktatás az erotikus. a zenei, vagy a jogi technikáról beszélnek. Max Weber szerint megkülönböztethetünk egyéni, szociál, intellektuális, és reáltechnikát.

Egyáltalán mit értünk technikán és a köznapi életben vele szinonimként használt technológián? Talán már a fentiekben leírtakból is következik, hogy technikán értjük azon eszközöknek, módszereknek, képességeknek a rendszerét, amelyekkel az ember a természet törvényeit alkalmazni tudja. 
A technológia viszont gyártási eljárások összessége, módszerek, és eljárások láncolata, amelynek során valamilyen nyersanyagból ipari készítményt, terméket állítanak elő, és hulladék is keletkezik. Az anyag átalakításához energiára és információra is szükség van még az ember közvetlen, vagy közvetett szellemi és/vagy fizikai munkája mellett.

A szociológusok elsősorban a társadalom technikalizálódását, illetve a technika társadalmiasulását vizsgálják. Ez ugyanazon dolognak a két oldala, és elsősorban gazdaságstatisztikai adatokkal, a termelés tőkeigényével, a gépek változásaival szokták mérni, illetve leírni. A valódi társadalmi hatások azonban inkább a technikának az életmódra, a hétköznapi életre gyakorolt hatásaiban, vagyis a minőségi változásokban ragadhatók meg. Sokféle összefüggésben vizsgálhatók a technika rendszerei, amelyek ismertetése itt nem lehetséges.

Aligha kell bizonyítani, hogy a technológia, a technika és az informatika szerves, szoros kapcsolatban vannak egymással. Ha rövid „képlettel akarnánk ugyanis leírni a technológia lényegét, akkor azt a következőképpen tehetnénk

Technológia $=$ Nyersanyag + Energia + Technika $($ Eszköz) + Tudás + Információ

A nyersanyag feldolgozásához tehát az energián, az eszközökön (gépek, múszerek, berendezések stb.) kívül információra is szüksége van az embernek, hogy a müveletek láncolata optimális végterméket, minimális hulladékot eredményezzen. Amint már az alapfogalmaknál láttuk, hogy a technika és a technológia miben különbözik, illetve miben azonos, és hogy a technika fejlődése a technológia fejlődését is jelenti. Láthatjuk, hogy a nyersanyag és az energia két olyan "kritikus környezeti problémát" okozó tényező, amely önmagában is középpontba állít mindent a ma embere és társadalmai számára. Vagyis a nyersanyag források kimerülése, a természeti környezet tönkretétele, vagy az energia elóállítás technológiájának lassú változása igazi kihívás. Az alternatív és megújuló energiatermelés elveinek és fizikai alapjainak tanítása a természettudományos alapoktatás, szak és felsőoktatás egyik reform területe kellene, legyen.

Aligha kell azt is bizonyítani, hogy a környezeti problémák miatt u.n. környezetkímélő technológiák terjedtek el, hogy a számítógéppel segített gyártás számtalan „válfaja” korszakán túlhaladva az intelligens technikák és technológiák képezik az egyik meghatározó pillért a negyedik ipari forradalom korszakában.

\section{Kétféle technológia}

Ebben a tanulmányban is fontosnak tartom megemlíteni, hogy a technológia fogalmi használatakor az oktatásban, -igy a szakképzésben és a felsőoktatásban is- lényeges megkülönböztetni kétféle technológiát.

Amit tanítunk (anyag-energia alapú, - információ alapú gyártás-szolgáltatás IKT)

Amivel feldolgozzuk a tananyagot> Oktatástechnológia, IKT> Digitális pedagógia

A szakképzésben ennek a kétféle technológiának $a z$ „együtt futása, egymásra hatása” az, ami érdekes és fontos. Számos oktatástechnológiai- digitális technológiai modell a piaci szférából származik, ott fejlesztették ki, mint pl. a Cisco Networking Academy Program, vagy az IBM Corporation e-learning oktatási modellje.

\section{A technikai fejlödés és hatótényezői}

Általában igaz az, hogy ha valamelyest követni akarjuk a technikai fejlődésnek a menetét, akkor célszerű valamilyen modellben gondolkodni. Különösen, ha a fejlődésnek az utóbbi két évszázadban bekövetkező trendjét akarjuk megragadni. Az emberi tevékenység alkotóelemeit /fizikai, szellemi/ a múködtetést /eszköz, technika/ és a termelés hatékonyságát össze kell vetni 
Árnyaltabb képet kapunk, ha az utóbbi néhány évtizedben történt változásokat a technikai fejlödés fö vonulataiban elemezzük. Nézetem szerint ez a fejlődés három területen mérhető le, amelyek a következők:

1, A villamos energia - benne a magenergia - tömegméretú felhasználása, ill. elterjedése gyökeresen átalakította az ipart, a mezőgazdaságot, a közlekedést, a háztartást, nem utolsó sorban az ember közvetlen lakóhelyi környezetét, életmódját.

2, Az irányítástechnika. Ma már elválaszthatatlan az embertól az irányítástechnika vagy másképpen az automatika. A modern irányítástechnika nem a célban, hanem a felhasználható eszközök rugalmasságában különbözik a korábbi konstrukcióktól, ill. mechanizmusoktól. Gépesítéstől a robotizációig, vagyis korunkig terjed az átfogóan is kezelhető automatizáció, elektronizáció, digitalizáció korszaka.

3, Az informatika. Ez a harmadik fő technikai vonulat, amelynek a fejlődése egyidős az emberi élettel. Az eszközök fokozatos fejlődése tette lehetővé a civilizáció kialakulását, fejlődését. Az elmúlt évszázadokhoz képest a mai kor informatikája elsősorban az eszközök gyorsaságában és rugalmasságában különbözik. (Lükő I. 2005) Ma már nem csak a gép-ember reláció, ember-ember, hanem a gép-gép reláció is megjelenik és terjed nem csak a csúcstechnika és az azt megtestesítő autógyártás terén, hanem máshol is.

\section{A technikai fejlödés következményei}

Kíséreljük meg a technikai fejlődés következményeit, kihatásait összegyűjteni. Ebből a leegyszerűsített megközelítésből kiindulva az alábbiakat tartom fontosnak kiemelni:

\section{Globális, környezeti következmények}

- Felbomlik az egyensúly az ember és a természet viszonyában. (Huber. J. 1989 ) Ennek egyik megtestesítője az ökológiai lábnyom.

- Sajátos életérzés alakul ki az emberiségben. Konrád Lorenz a civilizált emberiség nyolc halálos bűnéről beszél (Konrád. L. 1985)

\section{Társadalmi-gazdasági következmények}

- A sajátos életérzületek: elkábelesedés, technikafélelem, ökoterror,

- A termelésre hat ki elsősorban a csúcstechnika révén, ami abban ragadható meg, hogy a szalagrendszerű termelésbe integrálódik az egyedi gyártás, a szervizelés

- A digitális forradalom polarizálja az embereket, közösségeket és társadalmakat. Ez az u.n. digitális szakadékban testesül meg elsősorban.

\section{Társadalmi munkamegosztásban, kvalifikációkban és az oktatás-képzésben}

A digitalizáció, automatizáció nagymértékben hat a foglalkoztatottságra. Elsősorban a szektorok szerkezetében, arányaiban áll be jelentős változás. Kimutatható, hogy az u.n. harmadik szektorban foglalkoztatottak száma nő. Növekszik a távmunka, megjelenik az otthoni munka (home work), mint sajátos foglalkoztatási forma. Az alacsony kvalifikációt igénylő munkahelyek száma csökken, számos ágazat, munkahely és foglalkozás szúnik meg.

Itt jegyzem meg, hogy különösen a tengeren túli média „riogatja” az embereket, hogy egyik, másik szakma megszünik, nem lesz rá szükség, a robotok fogják felváltani pl. a taxisokat, a pincéreket. Az árnyaltabb és pontosabb felméréseken alapuló helyzetképre, vizionálásra lenne szükség.

-Változnak a kvalifikációk, a szakmák, foglalkozások is. Nem csak megszúnnek, hanem egyesek átalakulnak, modernizálódnak, és természetesen újak jönnek létre. 
-A gyermekek beleszületnek egy adott társadalom, adott korába, adott technikai-technológiai kultúrájába és abban szocializálódnak. A technikai szocializáció és a technikai nevelés szoros és szerves kapcsolata kitapintható, de a tudatos technikai nevelés meglehetősen mozaikszerúen valósul meg. Az új és modern eszközök, személyi használatú készülékek egyre több funkciókat tudnak, „okosak”, amelyeket nem mindig pozitív kapcsolatépítésre, tevékenységre használnak. Nagy a veszély különösen a fiatalabb korosztály net és mobil használata kapcsán, amire a digitális iskolának és a családnak, a szülőknek oda kell figyelni és óvni a felhasználókat.

\section{A teremtő technológiától az ipar 4.0-ig}

\section{A teremtő technológia}

Az alfejezet címe megegyezik Szántó Borisz könyvének címével(Szántó, 1990) A komplex társadalomtudományi megközelítésű műben a filozófiai, közgazdasági, a szociológiai aspektusok neves képviselőinek elvi-elméleti tételeit integrálja egy sajátos logikájú modell rendszerben.

Valójában Szántó Borisz volt az első Magyarországon, aki a technológia szélesebb és komplex megközelítésű technológia fogalmát, megnyilvánulásait rendszerbe gyűjtötte.

A teremtő technológia c. munkájában erről olvashatunk. Szántó Borisz könyvében. A nagy terjedelmü múben a technikai-társadalmi evolúció elméletéről írt és alkotott modellt.

Az u.n. egységesített technológiaelméletben többféle modellben fejti ki nézeteit. Az u.n statikus modell a közgazdasági menedzser megközelítésben érvényes és hasznos akár a fejlesztések megvalósításához is.

A modell alkotóelemei között a technika, mint eszköz, aza anyag és átalakítása mellett fontos szerepet kap a kulturális infrastruktúra.

4. táblázat: A technológia statikus modellje

\begin{tabular}{|l|l|l|}
\hline & & Know- how \\
& Élőmunka & Elméleti tudás \\
& Holt munka & Tapasztalat \\
& & Kulturális infrastruktúra \\
& Anyag, Energia, Információ \\
& Eszköz \\
\hline
\end{tabular}

Forrás: Szántó B. id. mü

Felhívom a figyelmet az anyag, energia, információ hármas tényezőire, valamint az elméleti tudás és a tapasztalat fontosságára.

Az anyagi, a szellemi és az érzelmi pólus hármasát emeli ki a generátor elv kifejtése után az „ember, mint technológiai motor" modelljében.

Automatizálástól az Ipar 4.0-ig

Az előző fejezetben már bemutattuk a gépesítés és automatizálás történeti korszakait. Most ezt egy másik vetületben, az elektronizáció-digitalizáció kapcsolódásában ragadjuk meg. Itt is a gépesítés az első szakasz/korszak, mert e-nélkül automatizálásról, tehát önmúködővé tételről nem beszélhetünk. Az automatizálás terjedésében meghatározóan fontos volt az elektronikai eszközök- elsősorban a félvezetők- elterjedése a legkülönbözőbb áramkörökben, technikai rendszerekben. Ezt a korszakot a 3. ipari forradalom korszakának is nevezzük, amelyben a PLC, vagyis a programozható vezérlések jelentették a „csúcstechnikát”.

Ezután érkeztünk a digitális rendszerek rohamos elterjedésével fémjelzett korszakhoz, a robotizáláshoz. 
5. ábra: Gépesítés-automatizáció-robotizáció

\section{Gépesítés Ipar 3.0}

Forrás: saját szerkesztés

A fenti ábrán megjelenő bővülő technikai-technológiai fejlődés jellemzői közül a digitalizáció és a robotizáció erőteljes térhódítása formálta a 4. ipari forradalomnak nevezett korszakot.

Ha definíciókban gondolkodunk, akkor ma már számos hosszabb és rövidebb terminológiával találkozhatunk. Ebben a definícióban markánsan megjelenik a valós fizikai(valós) és a virtuális környezetben megvalósuló teljes terméklánc életciklusaiban egy magasabb szinten valósul meg a szervezés és a szabályozás.

6. ábra Ökoszisztéma modell és a körforgásos gazdaság

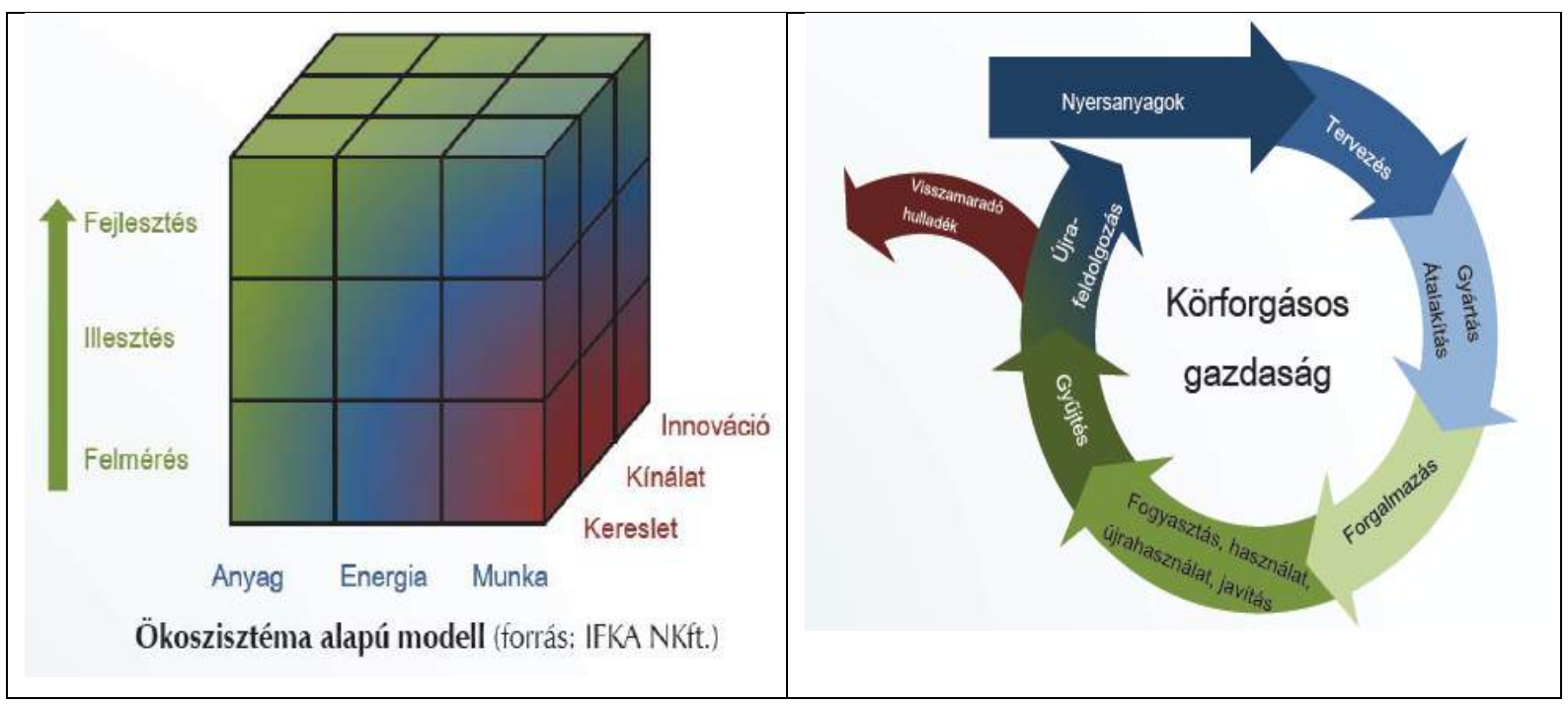

Az Ipar 4.0 fogalma, illetve komponensei, összetevői, illetve a használatuk az utóbbi pár évben „átrendeződött”, de ami maradandóan fix maradt, azokat az alábbiakban ábrázoltam: 
7. ábra: Az Ipar 4.0 összetevői, komponensei

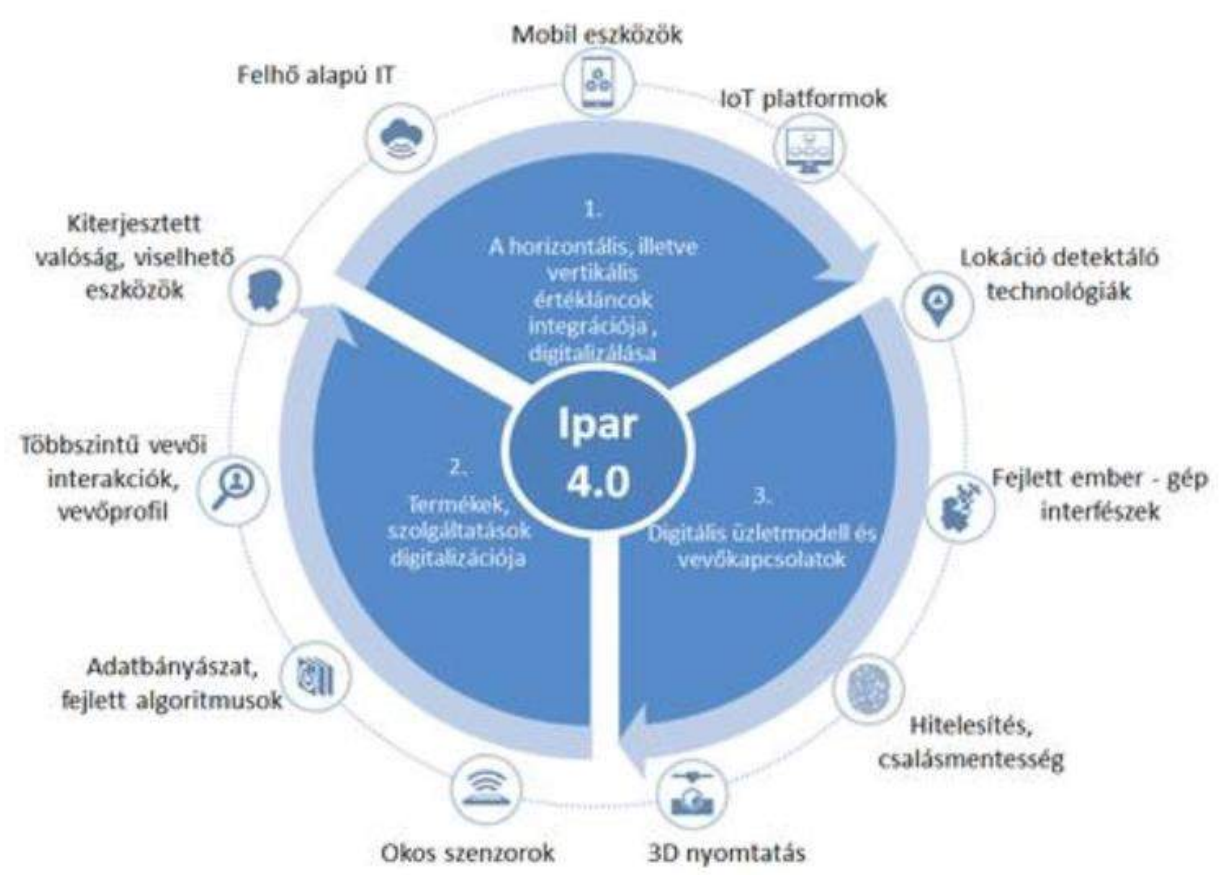

Forrás: https://leansixsigma.hu/files/Logisztika-4pontnulla.pdf

\section{A szakképzés fejlődése-fejlesztése}

Bevezető gondolatként azt tartom fontosnak megemlíteni, hogy az eddigiekben leírtakból is, de további vizsgálatokból különösen kirajzolódik, hogy egyfelől a szakképzés fejlödése és fejlesztése szervesen kapcsolódik a technológiai fejlödéshez, leginkább egy „követö” rendszerként. A követés kifejezés itt arra utal, hogy az iskolai szakképzés számos oktatási alrendszerekre jellemző inerciával bíró volta miatt eleve csak bizonyos fáziskéséssel „követi” a technikai-technológiai változásokat. Tetten érhető mindez a tananyagok, a tantervek és tankönyvek problematikáiban. Ez a legújabb kutatásifejlesztési projektekben is kiindulási alap, fontos célkitǔzés, hogy a hiányzó korszerű tananyagok és azok hordozói szolgáljanak az adott modell fejlesztési céljává. Lásd bővebben az MTA-BME OCD szakmódszertani programját.

Ugyanakkor hozzátehetjük, hogy- különösen a digitális átállás korszakában- ez nem egyszerűsíthető le a korszerű tananyag és hordozóinak a hiányára, mert számos más tényező és pedagógiai-didaktikai elem is szerepet játszik ebben. Ilyen pl. az állandó és a változó tudás viszonya, a példákat, vagy elveket tanítsunk leegyszerűsített kérdése, a modulok és a kompetenciák fogalmának folyamatos beépülése és tisztulása.

Másfelől az is kirajzolódik, hogy a szakképzéspolitika egyes országokban eltérő módon, de kontinentálisan és az EGK, majd EU szintjén markáns célkitǔzéseket fogalmazott/fogalmaz meg korszakról- korszakra. Vagyis a technológiai váltásokkal összefüggésben a szakképzéspolitikában is szemléletváltások (paradigmaváltások) következtek be.

Ezt a 30 éves vizsgálódási időtávlatunkat megelőző korszaktól, - vagyis az 50-es-60-as évektől kezdve a nyolcvanas kilencvenes évekig bezáróan - az európai integráció fókusztörekvéseként mutatta be a korábban már hivatkozott Csákó tanulmány.

A nemzetközi összehasonlító vizsgálatok számos dokumentumában, információs felületeken kirajzolódik az egyes országokban eltérő módon megvalósuló állami és gazdasági szereplők(piaci) közötti felelösség és befolyás megoszlása, a szociális partnerek szerepe. Alapvetően ez a viszony alakította ki a különböző szakképzési modelleket, azok jellemzőit is. Elég, ha most csak hivatkozom 
Günter Spreth professzor makro és mikroszintű modell elnevezéseire (iskolai, üzemi, iskola és üzem, kooperatív, MES-ILO), vagy ebben a tanulmányban is hivatkozott nemzetközi összehasonlító elemzés könyvben található gazdag ismertetésekre. (Benedek A. 2007. 80-84. oldalakon) Ezek segítségével könnyebb elhelyezni a hazai viszonyainkat bemutató- leíró elemzéseket is.

A megannyi elemző-értékelő, kutatási beszámolókban, publikációkban fellelhető szakképzésfejlesztéssel foglalkozó dokumentum valamiféle rendszerező-kategorizáló elemzése ebben a munkában képtelenség lenne, ezért csak néhány fontosabb korszakokra is jellemző tematizált elemet tudok kiemelni.

Egyik ilyen a tantervek, a tananyagok rendszerével, a modulok és a kompetenciákkal, vagyis a szakképzés tartalmi kérdéseivel foglalkozó munkák csoportja. Az ezredfordulót követő évtizedben dolgozták ki a kompetencia elvű és modulrendszerű képzést hazánkban. Ebből az időszakból, egészen pontosan az 1993-2005 közötti időszakból mutatom be a dokumentum rendszer és hordozójának (mágneslemez) a képét Pagonyné Mezősi Marietta prezentációjából átvéve.

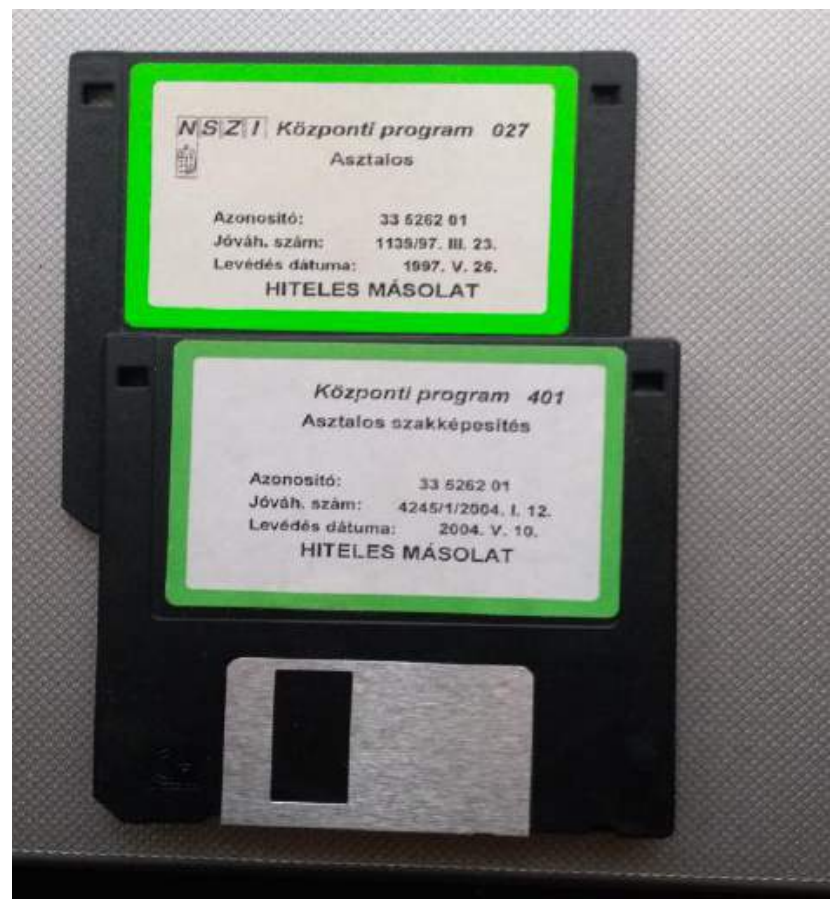

Forrás: Pagonyné, M.M.

8. ábra: Központi program mágneslemez hordozón

A következő időszakra, vagyis a 2006-2011-es időszakra a modulrendszerü, kompetencia elvü képzésre való átállás volt a jellemző, s közben 2010-ben a duális képzést is bevezették. Bár addig is jellemzően jelen volt, mintegy „kvázi duális forma”, innentől lehet egy erőteljesebb szakmapolitikai akaratot is érzékelni. A központi program időtervét bemutató ábrából látszik a különböző modulok alkotta kép, amit magunk között csak "szőnyegtervnek” neveztünk. 
9. ábra: Központi Program részlete

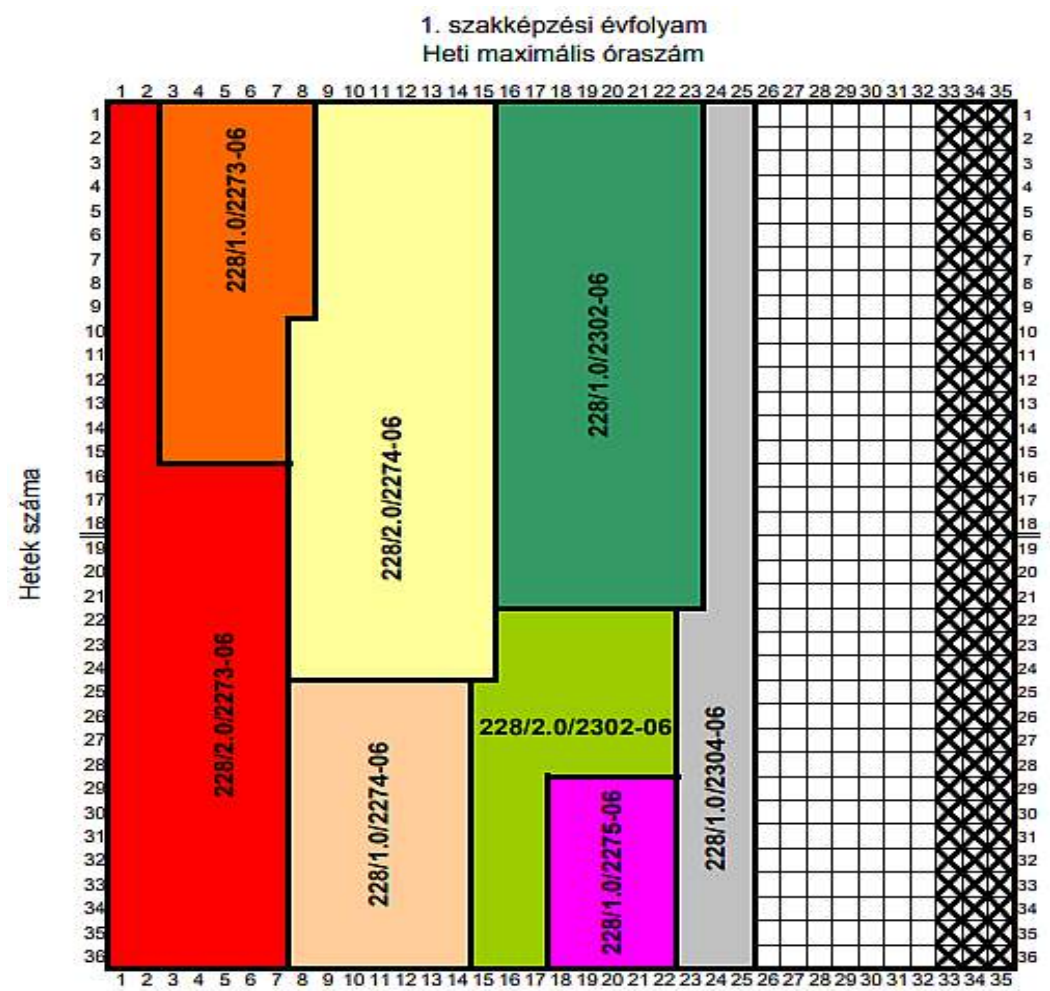

Forrás: Pagonyné, M.M

Király László igazgató (Király L. 2019) a XXI. ONK-n Pécsett tartott előadásában érintette a szakképzési tantervek változásait az utóbbi évtizedre sǔrítve, amelyet egy diakép segítségével be is mutatok.

10. ábra: Szakképzési tantervek evolúciója

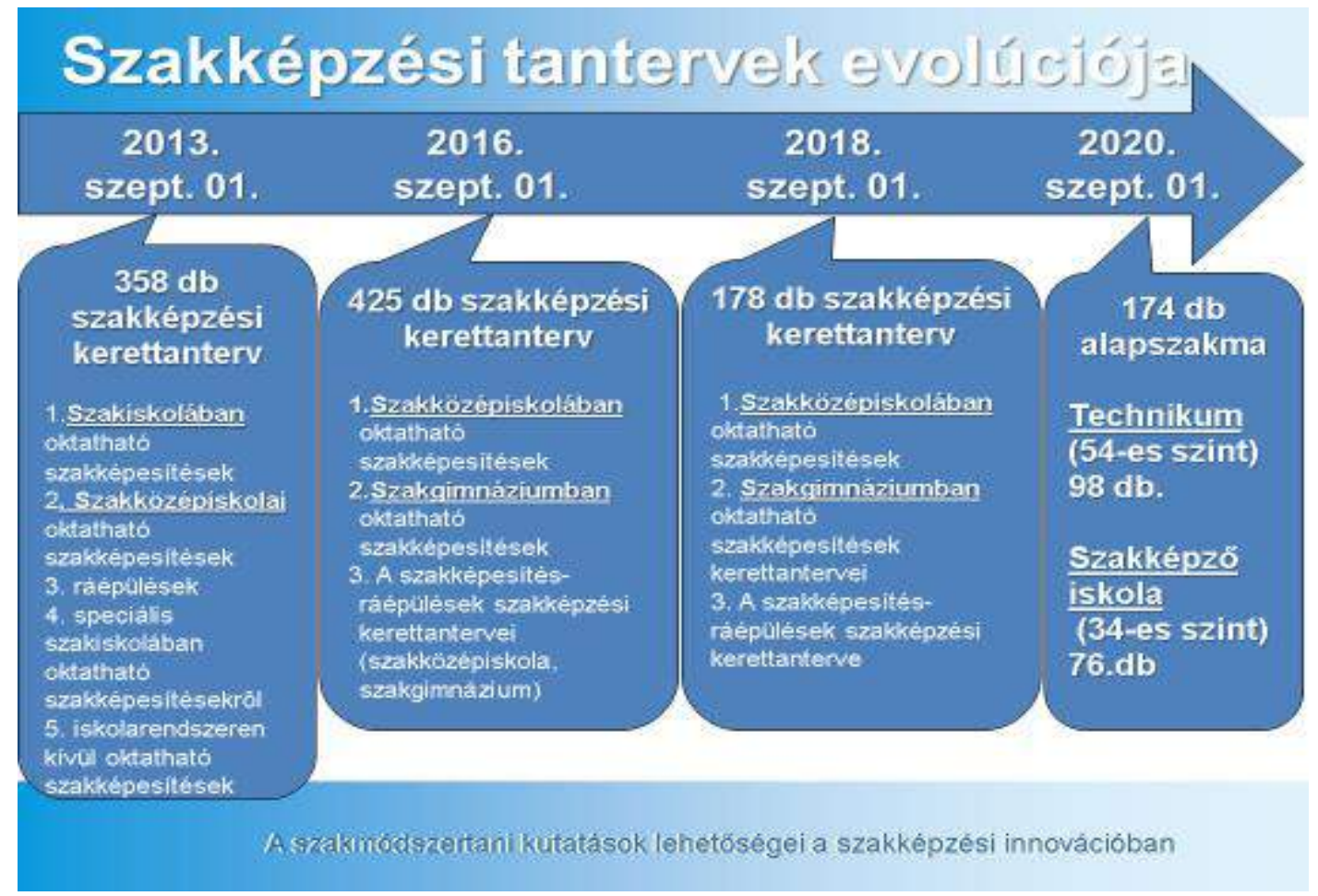

Forrás: Király L. 2019 
Ez az ábra többféle dologról informál. Egyik, hogy a hét év alatt negyedszer változnak a szakképzés iskolatípusai, képzési szerkezete, és ami még ennél is megterhelőbb, a tantervek. Közben már megváltozott a szakmajegyzék, az OKJ helyett 174 alapszakmát tartalmazó Szakmajegyzék született és januártól életbe lépett az új Szakképzési Törvény számos szervezeti változtatást is eredményezve. Ha kritikus szemmel nézzük azt az egyébként üdvözlendő szándékot, hogy az alapszakmásítással jelentősen lecsökkent az iskolarendszerben megszerezhető kétféle kvalifikációs szintű képzettségek száma,- az elgondolkodtató, hogy az 54-es szintkódon a technikumban több képesítést lehet megszerezni, mint a 34 -es szintkódú szakképző iskolában.

A technológiai fejlődést jellemző Ipar 4.0 korszakban a szakképzés fejlesztésében a digitális átalakulás, az újra automatizálás kihívásaira adandó válaszok megjelentek egy Szakképzés 4.0 elnevezésű középtávú fejlesztési stratégiában.(ITM, 2018). Ebben a dokumentumban megtaláljuk a részben kutatásokra is épülő diagnosztizáló, elemző és célokat, feladatokat is megjelenítő elemeket. Az átlátható, átjárható, duális, megtartó és karriert kínáló értékek mentén felépítették a három pillérre épülő stratégiát, amelyet az alábbi ábrával szemléltettek.

11. ábra: A Szakképzés 4.0 Stratégia pillérei

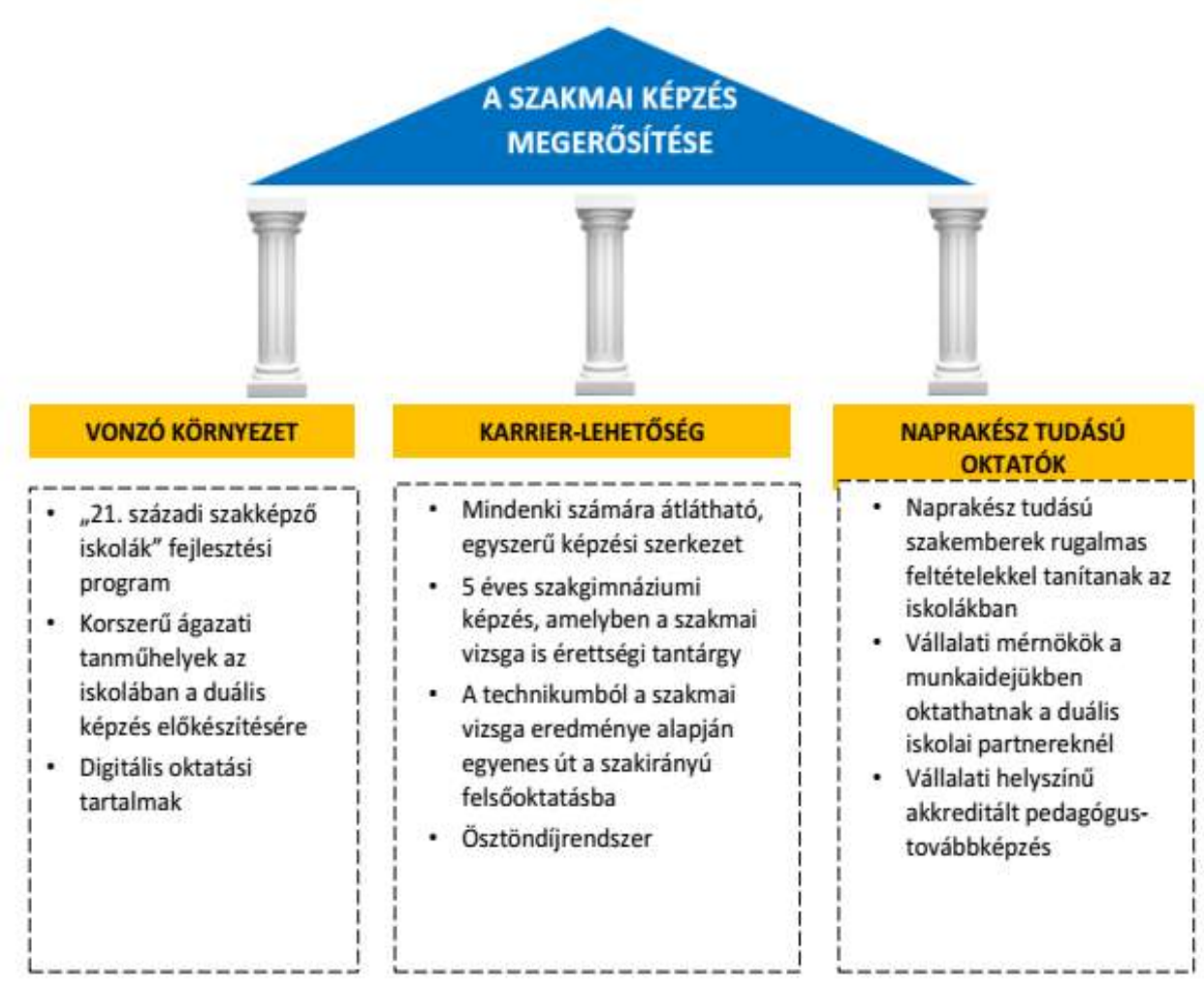

Amikor azt írtam, hogy részben kutatásokra épülő diagnosztizálások vannak a stratégiában, akkor azt kell tudnunk, hogy elsősorban a MKIK Gazdaság és Vállalkozáskutató Intézet vizsgálataira támaszkodnak. Időközben ugyanis az NSZFI átalakult NSZFH-vá, vagyis hivatallá, ahol ma már nem folytatnak szakképzéssel kapcsolatos tudományos igényű kutatást.

Ugyanakkor el kell ismerni, hogy a MKIK GVI Kutatási füzetek címú. kiadványukban színvonalas, megalapozott vizsgálatokat ismertetnek pl. az automatizáció lehetséges magyarországi hatásairól, járási munkaerö-piaci kitettségéröl.

Mik a jellemzői ennek a Szakképzés 4.0 Stratégiának?

- Egységben és párhuzamos feltételteremtéssel kezeli a szakképzés tartalmi, strukturális és a szervezeti-szerkezeti kérdéseit.

- Egységben kezeli az iskolai és a felnőttképzés keretiben megvalósuló szakképzést. 
- Szakít a felaprózott szakképesítési rendszerrel és elnevezésekkel és egy közös alapra, egykétéves időtartamú alapképszakmai, majd szakmai képzési szakszokra bontja 3-5 éves időtartamú szakközépiskolai és technikumi oktatást.

- Összekapcsolja a középfokú és a felsőfokú (akadémiai) oktatást elsősorban a technikus szakok tartalmi szabályozásán keresztül.

- Teljesen új és rugalmas együttmúködési formákat preferál a gazdaság vezérelt modellek révén, mint pl. Ágazati Képző Központok, Tudásközpontok, amelyekben az innováció több síkon és formában is megvalósulhat.

- Kezeli a nagyszámú iskolaelhagyók kérdését, illetve a problémára új képzési formát hoz létre.

\section{A digitális átállás és a digitális pedagógia}

A digitális eszközök és használatuk kapcsán „integrálódott” technológia vált a technológiai váltások innovációs motorjává. Ez a globális folyamat talán legjobban a digitális átállás fogalmában ragadható meg legjobban, ami jelenti egyfeloll azt, hogy az élet szinte minden területére kiterjed, vagyis a hétköznapi élet, a gazdasági élet, az oktatás világára egyaránt. Másfelől azt is jelenti, hogy egy minőségében másabb, integráltabb - intelligensebb rendszerekre cserélik a korábbi, már szintén magasfokon automatizált rendszert. Újra automatizálásként is jellemzik, illetve nevezik ezt az átállási folyamatot.

Ezzel a jelenséggel kapcsolatban teljesen átértékelődik a tanítás-tanulás, a szakmai tudás elsajátítás rendszere, illetve filozófiája is. A vállalkozásoknak nagy kihívás ez, amit sokan nem is tudnak követni. Kitapinthatók a tudományos megközelítések felöl is az átalakulásoknak/váltásoknak a szakaszhatárai. Kroó Norbert akadémikus ezt úgy fejezi ki, hogy: a felsőoktatásban- elsősorban a műszaki, természettudományi felsőoktatásban paradigmaváltás következett be, mert "a 20. században azt értettük meg, amit meg tudtunk mérni. A 21. században azt értjük meg, amit ki tudunk számítani". (Kroó, 2017) Vagyis, a számítás-tervezés és a modellezés segít az összefüggések megértésében.

Másként közelíti meg ezt a paradigmaváltást Pálmay Zoltán, aki már 1989-ben leírta gondolatait erről. (Pálmai, 1989) A technológia, mint tudatosan irányított folyamat az energia alapú technológiákról fokozatosan tért át az információ alapú technológiákra. vagyis az anyagtechnológiákat a strukturált technológiák korszaka, majd az információs technológia korszaka követte.

Ezek a gondolatok vezetnek át minket most a digitális átállás oktatási területére, a digitális pedagógia világába.

Már az eddigiekből is nyilvánvalóvá vált, hogy ez a digitális átállás alapvetően átrendezi a munka világát, a foglalkoztatottságot, a szakmák, tevékenységek rendszerét. Szoktak nagyon sötét képet festeni arról, hogy egyes szakmák teljesen eltünnek, hogy nem lesz szükség pincérekre, gépjármúvezetőkre sem a robotizáció miatt. A tudományos igényű felmérések, diagnosztizálások azonban ennél jóval árnyaltabb képet mutatnak.

McKinsey tanulmányából kiderül, hogy különböző foglalkozásokban hogyan alakul (mi várható) a digitalizálhatóság terén. (McKinsey 2018) Ebből merítettek és adaptálták a magyar viszonyokra is a Szakképzés 4.0 fejlesztési stratégia írói is, amit az alábbi ábrával szemléltettek a már hivatkozott Szakképzés 4.0 fejlesztési stratégiai dokumentumban. 
12. ábra: A digitalizálhatóság aránya a különböző foglalkoztatási kategóriákban

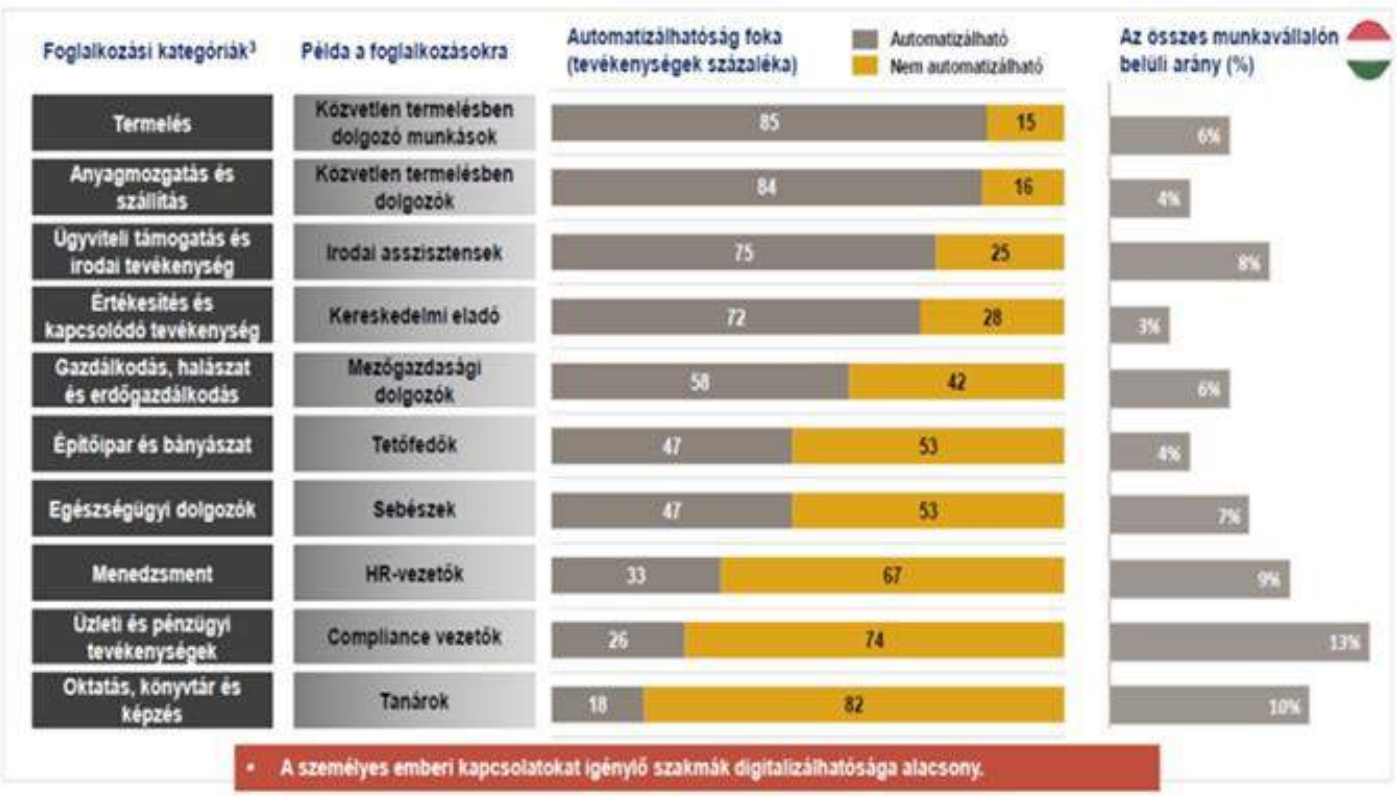

Forrás: McKinsey 2018.

„Bíztató", hogy a tanári foglalkozás esetében 82 \%-ban nem automatizálható a tevékenység. Ezekből a hazai viszonyokra jellemző adatokból lehetett kiindulni és az elveket, koncepcionális célokat megfogalmazni a szakképzés egészére és ágazataira vonatkozóan.

Ezen gondolatok után most már jöhet a mélyebb és differenciáltabb vizsgálódás a digitális pedagógiáról.

Magát a fogalmat elég sokféleképpen definiálják, összemossák, szélesre vagy éppen szúkre fogják a tartalmak körét stb. Érdemes Horváth Ádámot idézni, aki szerint: A digitális pedagógia nem egyenlő a digitális eszközökkel végzett pedagógiával. Felfogható azonban úgy, hogy a digitális életre való felkészítéssel egyenlö a digitális pedagógia.

„A digitális pedagógia az a neveléstudományi részdiszciplína, amely az általános pedagógiaineveléstudományi elvekre épülöen specifikus oktatástechnológiai, módszertani és didaktikaikommunikációs tartalmi részeivel egyfelöl elvi-elméleti támpontokat, másfelöl konkrét gyakorlati megvalósítási módokat, mintákat ad, megmutatva információs társadalmunk képviselőinek mindazokat a kihívásokat és lehetöségeket, melyet ma az IKT biztosít. A pedagógusok felkészítésében kiemelkedő szerepe van (kellene, hogy legyen) a digitális pedagógiai ismereteknek és készségeknek". (Molnár, Gy., 2018)

Ha a hazai viszonyokat nézzük, akkor a felsőoktatásban való elterjedésnek ugyancsak az elején járunk, legalábbis, ami a deklarált és szervesült hallgatói felkészítést jelenti. Ebben élenjáró a BME Műszaki pedagógia Tanszéke, ahol elöször vezették be hazánkban a tantárgyként való oktatását. Kialakult egy nemzetközi kapcsolatokkal és megmérettetéssel is rendelkező hazai kutató-fejlesztő múhely.

A digitális pedagógiának sokféle hatását lehet ma vizsgálni. Ha az egész neveléstudományra vonatkozó hatókört vizsgálunk, akkor leginkább a dominancia váltásokról beszélhetünk.

Nagy József három dominanciaváltásról beszél, amelyeket most itt nincs lehetőség részletezni, csupán a harmadikról írok röviden. A harmadik dominanciaváltás a mára kialakult új helyzetben vált lehetővé, ugyanis a kompetencia elvü és alapú intézményes nevelés és tartalmi szabályozás keretében a személyiség fejlesztését a kialakítandó kompetenciái, személyiség komponensei teszik lehetővé.

Nézetem szerint a mai korban elkezdődik egy negyedik dominancia váltás is, amit lehet a mobil tanulás, a digitális pedagógia dominanciájának is nevezni. Tanúi vagyunk az iskola falait feszegető változó 
tanulási környezet hatásainak, az IKT alapú, nagyon sokszínű és változó, téri és időbeli lefolyású tanulási rendszer kibontakozásának, amit mai fogalmainkkal alig-alig tudunk leírni, megragadni. Erről írtak a Benedek András szerkesztette Digitális pedagógia c. könyv több szerzője is. (Szerk.: Benedek, 2011) (Molnár Gy. 2018)

Benedek András nyomán a fókuszálásokról röviden: A digitális pedagógia a következő tartalmakra és tevékenységekre, valamint kommunikációs eszközökre fókuszál: kommunikáció menedzsment kialakítása a tanulásban, kollaboratív és kooperatív tanulás, blogok használata, virtuális intézmények kapcsolata. Mindezekről a formálódó pedagógiai formációkról szól a Benedek András által szerkesztett Digitális pedagógia című egyetemi tankönyv.(Benedek, 2008).

A Nemzeti Infokommunikációs Stratégia 2014-2020 címet viselő dokumentum az Infokommunikációs szektor fejlesztési stratégiája (2014-2020) alcímet viseli és jelzi, hogy egy társadalmi szektorként kezeli a valóságban mindenre kiterjedő elképzeléseket. A Nemzeti Infokommunikációs Stratégia horizontális és vertikális pillér rendszerében a Digitális Állam, a Digitális Kompetenciák, Digitális infrastruktúra, Digitális gazdaság mentén készült a SWOT analízis és a fejlesztési célok megfogalmazása.

Fontos megemlíteni, hogy sok kolléga közremúködésével elkészült és 2016-ban kiadták az oktatási szféra számára irányt mutató Magyarország Digitális Oktatási Stratégiáját. Ebben a stratégiában is az egyik kulcsfogalom a digitális kompetencia az az ismeretek, képességek és attitűdök integrált rendszere.

A digitális kompetencia magában foglalja az információs társadalmi technológiák magabiztos és kritikus használatát a munka, a szabadidő és a kommunikáció területén. Ez az IKT terén meglévő alapvető készségeken alapul: számítógép használata, információ visszakeresése, értékelése, tárolása, előállítása, bemutatása és cseréje céljából, valamint a kommunikáció és az együttmüködő hálózatokban való részvétel érdekében az interneten keresztül.

Ebből a köznevelést érintő területre az $\mathrm{OH}$ és további négy konzorciumi partner az EFOP 3.2.1-15 keretében u. n. digitális kompetencia keretrendszert dolgoz ki. Ebben az $\mathrm{OH}$ partnereként a BME MPT munkacsoportja fogja össze a keretrendszer kidolgozását. Négy célcsoportra terjed ki a keretrendszer. Ennek egy összefoglaló ábrája jól mutatja a tanuló, a pedagógusi, a vezetői és az intézményi keretrendszereket, illetve ezek kapcsolódásait.

13. ábra: Digitális kompetencia keretrendszer és célcsoportjai

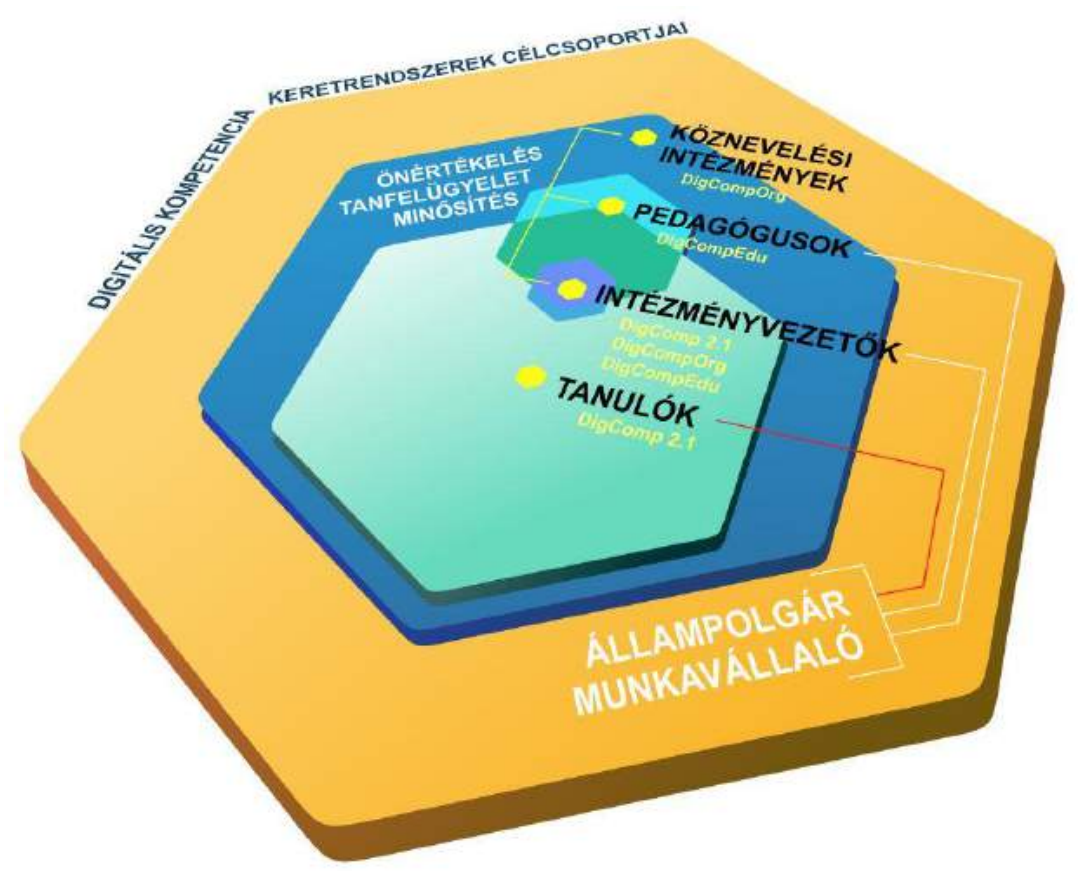

Forrás: Medve Katalin $\mathrm{OH}$ 


\section{A pedagógusképzés, szakmai tanárképzés és a szakmódszertan kapcsolata}

Az IKT eszközök használata a pedagógus szerepváltozásokhoz vezetett, ezek inspiráltak sok kutatót és szerzőt, hogy ezzel a kérdéskörrel foglalkozzanak.

A szerepváltozások mellett a generációs különbségek is meghatározóak lettek. Ezek elsősorban a korszerű eszközök környezetében felnövekvő fiatalok és az őket tanító, az eszközöket nem annyira ismerő és használó pedagógusok között meglévő és olykor éles kompetencia különbségekben ragadhatók meg. Prensky elnevezésében ismerhettük meg a digitális bennszülöttek és a digitális bevándorlók kifejezést. (Prensky 2001).

A szakmai tanárképzés és az IKT kapcsolatában sajátosságokat is felfedezhetünk. Erről a témakörről is nagyon gazdag a szakirodalom tárháza, melyek közül néhányat kiemelünk és ismertetünk röviden.

Átfogóan és széles körre kiterjedően foglalkozott az IKT eszközök használatával elsősorban a mentortanárok és a mérnöktanárok képzési területén, valamint a szakmai tankönyvek használatával, a prezentációkészítés kérdéskörével Simonics István. Külön vizsgálta a szakmai oktatás szakmódszertani vonatkozásait, illetve a tankönyvek és az IKT szerepét, viszonyát ehhez kötődően. (Simonics István 2017, 2015/a,b/c, 2014)

A Budapesti Műszaki és Gazdaságtudományi Egyetem, Műszaki Pedagógia Tanszékén folyó pedagógusképzések rendszere is nagy átalakuláson ment keresztül. A paradigmaváltás keretében szakítottak a tananyagközpontú, oktatóközpontú hagyományos tanuláselméletekkel és módszerekkel, $\mathrm{s}$ helyette az úgynevezett IKT alapú atipikus tanulási formákra tértek át. Ennek számos kutatásifejlesztési mozzanatáról, illetve eredményeiről nincs lehetőség részletesen írni, csupán jelezni tudom, hogy a következő alfejezetmben egy konkrét modellt vázlatosan bemutatok.

\section{Nyitott tananyagfejlesztési modell (OCD) Szakmódszertani innováció}

A szakmódszertan, mint tudomány örvendetes módon az MTA elnökségének is a figyelmébe került. A közismereti tanárképzéshez kapcsolódóan először 2014-ben hirdették meg a Tantárgypedagógiára változtatott Szakmódszertani pályázatot, majd 2016-ban nagyobb összeggel megismételték. A nyertesek négy évre kaptak támogatást a különböző tantárgypedagógiai /szakmódszertani területek kutatására.

A Budapesti Műszaki és Gazdaságtudományi Egyetem kutatócsoportja Benedek András professzor irányításával megkezdte munkáját a szakmai tanárképzés és a szakképzés ún. nyitott tananyagfejlesztési modelljének kidolgozásával. A koncepciónak a lényegi elemei közé tartozik a szakképzési problémák egyik kivezető útjának tekinthető képi tanulás jelentőségének a felismerése. Ennek hatására jött létre a BME-n a Képi Tanulási Múhely (Visual Learning Lab, VLL), Ehhez egy nemzetközi kommunikációs rendszer, konferencia és évente megjelenő angol nyelvű könyvsorozat kapcsolódik. Nyíri Kristóf „Vizuális hazatérés” c. munkájában hívja fel a figyelmet a képeknek a kommunikációban, így az ismeretközvetítésben/átadásban betöltött szerepére. Az OCD (Open Content Development) a szakképzés valós problémáira választ adó program, amelynek két fő pillére a képi tanulás és a mikro-tartalmak tervezése. Ebben a folyamatban a felsőoktatás oktatói mellett a szakképző iskolák hálózatának tanárai, - és ami nagyon lényeges sajátosság - a tanulói vesznek részt együttes munkában. 
14. ábra: Az OCD modell főbb kimeneti és bemeneti tényezői

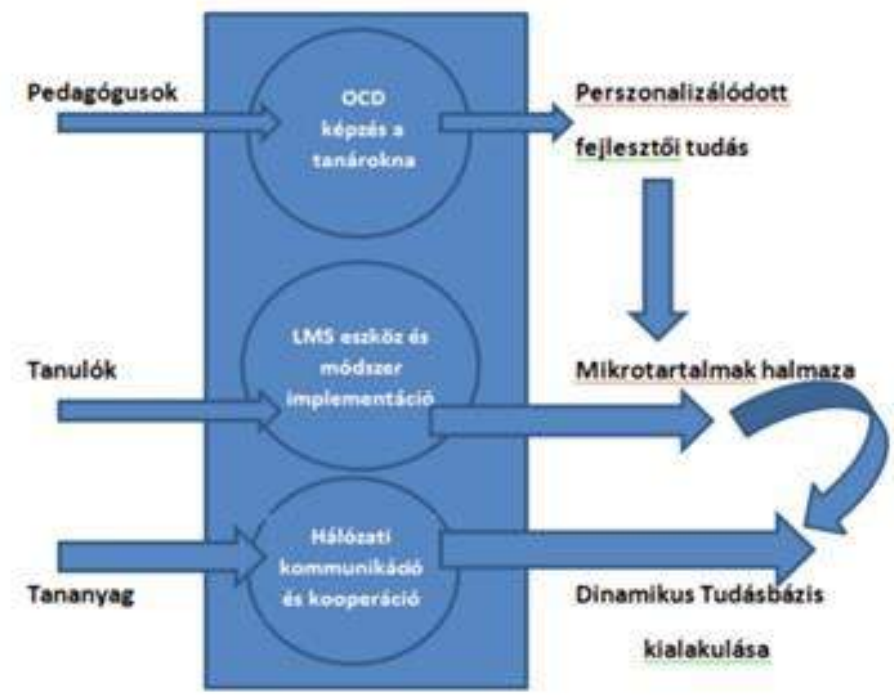

Benedek A. ábrája

Néhány konkrét eredményt mutatok be ebből a programból.

a) A folyamatszimulációs modell

15. ábra: A folyamatszimulációs modell egy részlete

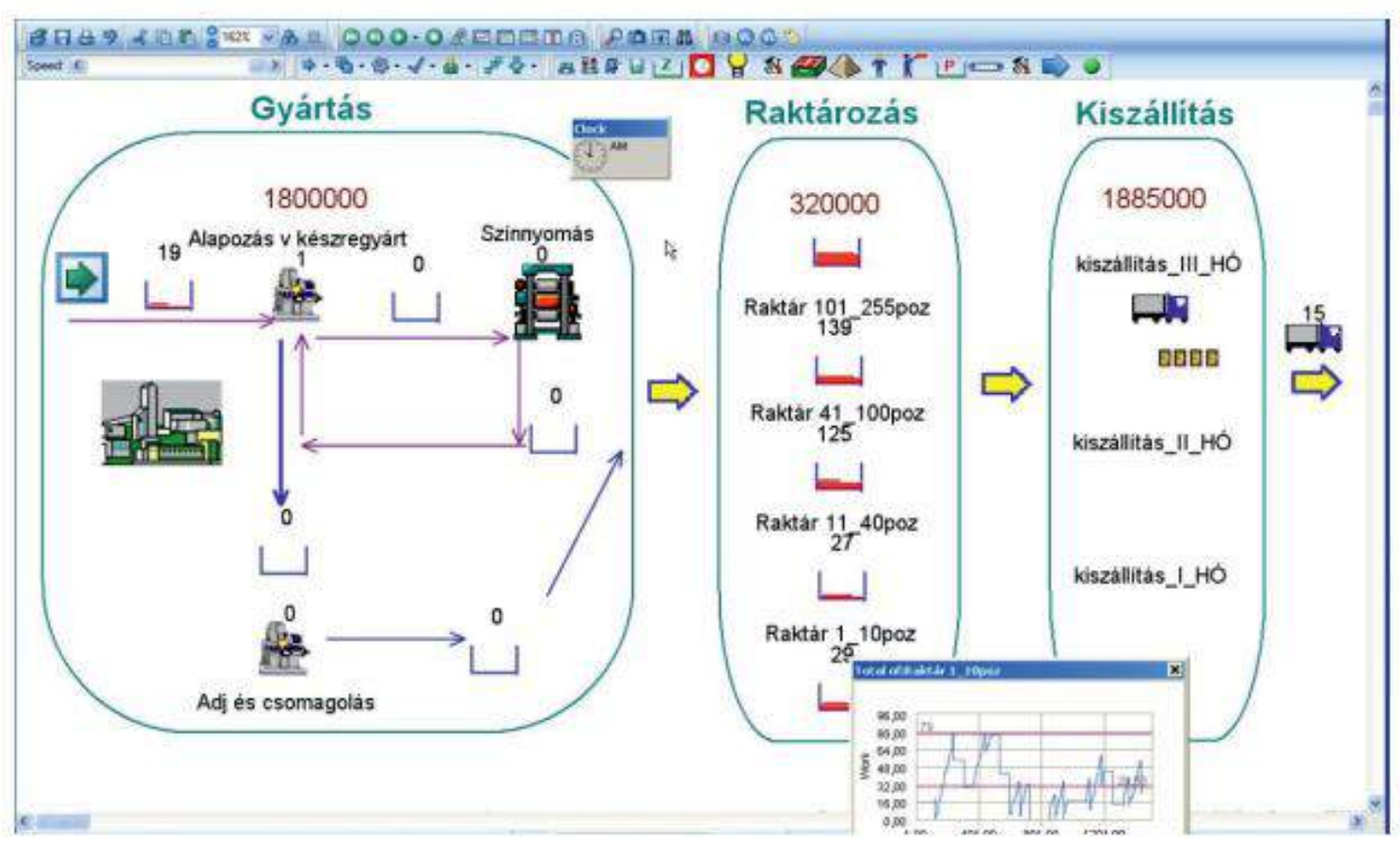

Forrás: Molnár Gy. 2018

\section{Faipari tudásközpont}

Az Ipar 4.0-hoz szervesen kapcsolódó stratégia a Szakképzés 4.0. Ennek a középtávú szakképzésfejlesztési stratégiának a fő pilléreihez és célkitúzéseihez kapcsolódóan lehetőség van/lesz 
felsőoktatási intézményeknek és szakképzési centrumoknak a meghatározó vállaltokkal együtt innovativ oktatásfejlesztési modellben megvalósítani az egymásra épülő ágazati oktatási-képzési feladatokat. A szakképzés esetében nagy lehetőség az, hogy az országban egyedül Sopronban képeznek faipari mérnököket és a Bázisiskolai Hálózat iskolái, az ott tanuló asztalos és faipari technikus tanulókkal, tanárokkal és szakoktatókkal a Szakképzési Centrumokon keresztül a gazdaság vezérelt oktatás modelljét kialakíthatják. A pilot projekt jellegű megvalósítás tervezete már ott van az ITM asztalán. Ennek a modellnek az elvi kialakítását szemlélteti az alábbi ábra, amelyben jól látható a fenntarthatóságra koncentráló egyik pillér és az oktatásra, a digitális tananyagfejlesztésre, a szakmai pedagógusok továbbképzésére koncentráló másik pillér.

16. ábra: Faipari Tudásközpont pillérei, tevékenységei

\section{Faipari Tudásközpont pillérei, tevékenységei, részlegei}

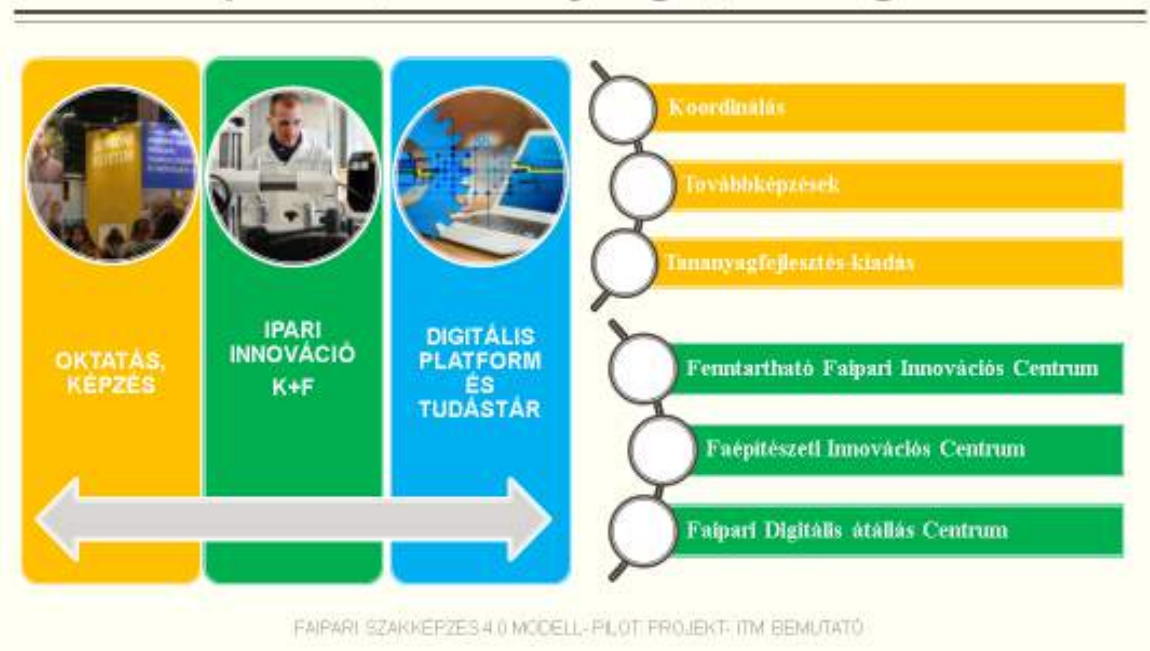

Forrás: Lükő, 2019

\section{Digitális Közösségi Alkotómühelyek DKA (Digitális „,közmühely”)}

Az ITM támogatásával szisztematikusan egy szakképzési centrumokra "telepített” hálózat formájában hozza létra elsősorban a szakképzés pályaorientációs tevékenységének hatékonyabbá tételéhez, vagyis a vonzó szakképzés fő célkitűzéséhez. Az alkotó műhelyekben a barkácsolás kézi és gépi szerszámaival számos fém és fa anyagmegmunkálást végezhetnek, de van benne okos varrógép, 3D nyomtató, mikroelektronikai áramkörök, és lehet programozni, robotokat építeni. A tanulóknak készült 15 tananyagból néhánynak a céljait, tematikáját foglaltam össze az alábbiakban képekkel. 
17. ábra: DKA múhely pillanatképei, tevékenységei

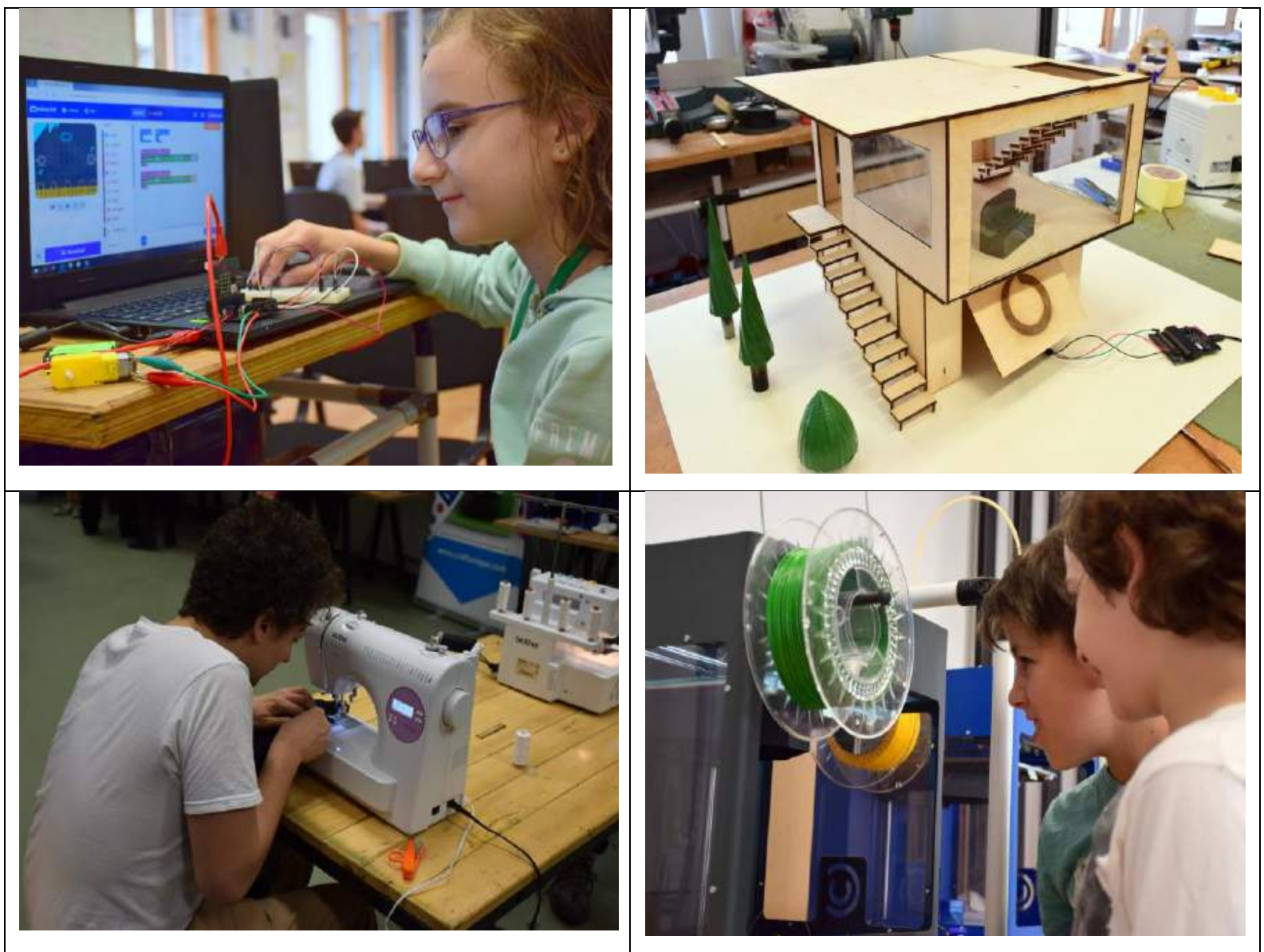

Forrás: saját szerkesztés a MAKERSPACE honlap képei alapján

\section{Összefoglalás}

A tanulmány célkitúzéseihez és vállalt feladataimhoz illeszkedően a Bevezetőben a téma behatárolását, fókuszterületeit érintettem, kiemelve, hogy az átfogott három évtizednyi időszak elejére és a végére fókuszáltunk. Természetesen a közbülső időszakokról is történt kellőképpen részletes és mély bemutatás úgy a technikai-technológiai fejlődés, mint a szakképzés átalakulásának szakaszolt korszakairól.

Megindokoltam a „mozaikos” jelző használatát. A tanulmány forrásai elsősorban a hazai viszonyokat mutatták be, de olyan nemzetközi kitekintést is végeztünk, amely kellöképpen beágyazta és összehasonlíthatóvá tette a hazai fejlődést, a szakképzés alakulását.

\section{A technológiai fejlődés, mint az innováció motorja és dimenzionális kapcsolatai}

A spontán fejlődés és a tudatos fejlesztés elsősorban a technikai eszközök és a tudatosan, irányítottan történő alkalmazásokban válik a technológiai fejlődés alkotó részévé. Közvetlen fogaskerékszerü kapcsolódása részben az oktatás, a képzés rendszerét, másrészt a gazdasági- társadalmi környezet egészére kihat, forgásba hozza. Ezek a triviálisnak túnő kapcsolódások jelképezik az egymásra hatás rendszerszerű együttmúködését, egyben jelzik, hogy ha a „fogaskerekek közé beszorul valami, akkor a gazdasági-társadalmi hasznosulás, a tudástermelés és megosztás is csorbát szenved. 
18. ábra

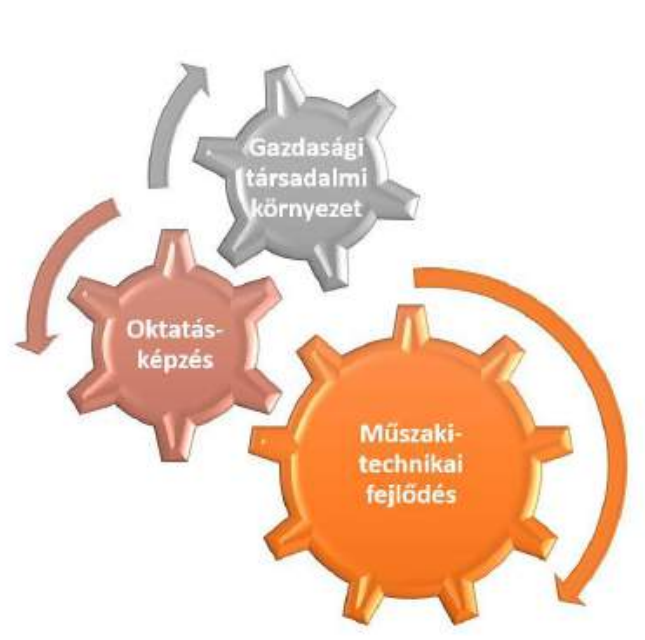

A vizsgálódás-kutatás eredőjének néhány jellemzője táblázatos összefoglalása a szakképzés szerkezetét, tartalmát meghatározó modellek nemzetközi és hazai összehasonlításában.

\section{5. táblázat}

\begin{tabular}{|c|c|c|}
\hline Korszak & Nemzetközi jellemzők & Hazai jellemzők \\
\hline 1950-1989 & $\begin{array}{l}\text { integráció a közösségben, a termeléstől } \\
\text { a szolgáltatás felé, a 3. ipari forradalom } \\
\text { korszaka szociális problémák és } \\
\text { partnerek kezelése, sokféle szakképzési } \\
\text { modell jön létre, az állam és gazdaság } \\
\text { szerepvállalásai módosulnak }\end{array}$ & $\begin{array}{l}\text { erős iparosítás, a szakképző intézményi } \\
\text { hálózat kiépítése, fejlesztése, majd } \\
\text { fokozatosan csökken a nehézipar szerepe, } \\
\text { kvázi duális szakképzés demokratizálódás } \\
\text { előszelei, }\end{array}$ \\
\hline 1989-1995 & $\begin{array}{l}\text { jelentős társadalmi- politikai események } \\
\text { Európában, a technikai-technológiai } \\
\text { fejlődés gyorsulása, ennek } \\
\text { következményei a gazdaságban és a } \\
\text { szakképzésben, az állami } \\
\text { szerepvállalások, a gazdaság és a } \\
\text { szociális partnerek szerepmegoszlása } \\
\text { fokozatosan finomul, új képzési formák } \\
\text { és paradigmák (a formális képzésen kívül } \\
\text { szerzett tudás és elismerése) }\end{array}$ & $\begin{array}{l}\text { rendszerváltás, összeomlik a gyáripar, nagy } \\
\text { munkanélküliség, az első Szakképzési } \\
\text { Törvény, OKJ, NSZI, MSZT, decentralizáció, a } \\
\text { szakmai pedagógusképzés megerősödése, } \\
\text { jelentős szakképzés-pedagógiai kutatási } \\
\text { műhelyek, innovatív külföldi modellek } \\
\text { adaptálása (modulrendszerű szakképzés) }\end{array}$ \\
\hline $1995-2010$ & $\begin{array}{l}\text { kompetencia modellek, a vizsgáztatás } \\
\text { rendszerének vizsgálata, fejlesztése, } \\
\text { kétféle innovációs modell (botton up, } \\
\text { top-down), erős automatizálás, } \\
\text { digitalizálás és szakképzési megoldásaik, } \\
\text { technológiaváltás (3.-és -4. ipari } \\
\text { forradalom) }\end{array}$ & $\begin{array}{l}\text { nemzetközi szakképzés-fejlesztési projektek } \\
\text { (Világbanki, PHARE), a formális képzésen } \\
\text { kívül szerzett tudás és elismerése) } \\
\text { szervezeti átalakítások (TISZK, OM-NGM,) } \\
\text { modulrendszerű és kompetencia elvű } \\
\text { képzésre való áttérés }\end{array}$ \\
\hline $2010-2020$ & $\begin{array}{l}\text { más típusú munkaerő vándorlás, a } \\
\text { digitális pedagógiai és módszertani } \\
\text { kutatások erősödése, tanulói hálózatok } \\
\text { erősödése, a szakképzés-felnőttképzés } \\
\text { és felsőoktatás kapcsolatának } \\
\text { újragondolása és fejlesztése }\end{array}$ & $\begin{array}{l}\text { szervezeti, irányítási- fenntartási } \\
\text { átalakítások, területi dimenziók, } \\
\text { hiányszakmák, lemorzsolódás kihívásainak } \\
\text { kezelése, a gazdaság vezérelt szakképzés } \\
\text { stratégia és modell, új szakképzési törvény, } \\
\text { és szakmajegyzék, szervezeti (ITM, } \\
\text { Szakképzési Centrumok), szerkezeti és } \\
\text { tartalmi átalakítás }\end{array}$ \\
\hline
\end{tabular}


Az elmúlt négy évtized szakképzést befolyásoló tendenciái

6. táblázat

\begin{tabular}{|c|c|c|c|c|c|c|c|c|}
\hline \multirow{3}{*}{$\begin{array}{l}\text { Terület } \\
\text { Állami- gazdálkodói } \\
\text { szerepvállalás }\end{array}$} & \multicolumn{4}{|c|}{ Nemzetközi tendencia } & \multicolumn{4}{|c|}{ Hazai tendencia } \\
\hline & $x x x$ & & & & $x x x x$ & & & \\
\hline & & $x x$ & & & & $x x x$ & & \\
\hline & & & $x x$ & & & & $x x$ & \\
\hline & & & & $x x$ & & & & $x x x$ \\
\hline \multirow[t]{4}{*}{ Szakmák száma } & $x x$ & & & & $x x x$ & & & \\
\hline & & $x x x$ & & & & $x x x x$ & & \\
\hline & & & $x x$ & & & & $x x x$ & \\
\hline & & & & $x x$ & & & & $x$ \\
\hline \multirow[t]{4}{*}{ Centralizáció-decentralizáció } & $x x x$ & & & & $x x x x$ & & & \\
\hline & & $x x$ & & & & $x x x$ & & \\
\hline & & & $x x$ & & & & $x x$ & \\
\hline & & & & $x x$ & & & & $x x x x$ \\
\hline \multirow{4}{*}{$\begin{array}{l}\text { Szakképzés- pedagógiai } \\
\text { kutatások }\end{array}$} & $x x$ & & & & $x x$ & & & \\
\hline & & $x x x$ & & & & $x x x$ & & \\
\hline & & & $x x x x$ & & & & $x x$ & \\
\hline & & & & $x X X$ & & & & $x$ \\
\hline
\end{tabular}

A digitális pedagógia fejlődésének szakaszai

19. ábra: A digitális pedagógia fejlődésének állomásai

- IKT alkalmazás a tanárképzésben

- Blended rendszer

IKT és

hagyományos Okt.

\section{Digitális pedagógia}

Web2.0

- IKT eszközhaszn.

- Digitális pedagógia 1,2

- Hálózati tanulás
- Mobil tanulás

- Felhó alapú tanulás

- Nyilt tananyagfejl 
A digitális pedagógia elvi-elméleti hátterét érintő elemzésünk során kitértünk a nevelés-oktatás dominanciaváltásaira, a digitális kompetencia fogalmára és összetevőire, a négy célcsoportra bontott köznevelési rendszer számára készülő digitális kompetencia keretrendszer lényegére.

Triviális volt, hogy a digitális pedagógia a mi szempontunkból a szakmai pedagógusképzésben megjelenő kutató-fejlesztő tevékenységében ragadható meg a legjobban. Példáink jól bizonyítják, hogy ezen a területen jól kitapintható a paradigmaváltás.

\section{Felhasznál szakirodalom}

- András B., Ágnes V. (2017): Virtuál reality- Real Visuality. Peter Lang EDITION, Frankfurt am Main.

- Benedek András (1987): Szakképzés és gazdaság (Adaptív szakképzési modell) In: Szakképzési Almanach Válogatás az OPI Szakképzési Igazgatóságának munkáiból 1984-1986 Budapest, OPI, 21-42. o.,

- Benedek András (2007): Nemzetközi összehasonlító elemzés a szakképzésben NSZFEI Budapest,

- Benedek András (2008): Digitális pedagógia Typotex, Budapest.

- Benedek András(2003): Változó szakképzés Okker, Budapest.

- Csákó Mihály (2016): A szakképzés és az európai integráció. In: Educatio 2016 tavasz 3-11. o.,

- Dieter Blaschke, Martin Koller, Gerhard Kühlewind (1990): Qualifizierung in den neuen Bundesländern IAB Nr. 7/1990,

- Farkas J.(2002): Információs, vagy tudástársadalom? Infónia - Aula, Budapest,

- Prof. Dr. Günter Spreth (2001): Möglichkeiten und Begrenzungen des Modulprinzipien in der internationalen Berufsbildungskooperation In: Modularisation in der beruflichen Aus, -und Weiterbildung, DSE Magdeburg,

- Huber, Joseph (1989): Eine sozialwissenschaftliche Interpretation der Humanökologie. In: Bernhard Glaeser: Humanökologie, Westdeutscher Verlag GmbH., Opladen,

- ITM (2019): A szakképzés és felnőttképzés megújításának középtávú szakmapolitikai stratégiája. Budapest,

- Király L. (2019): A digitális pedagógia módszertanának fejlődése a szakképzési kerettantervek változó világában- iskolai szempontból. PPT XIX. ONK Pécs,

- Konrad Lorenz (1985): A civilizált emberiség nyolc halálos büne Ikva Kiadó, Sopron,

- Kroó N.(2013): Tudomány és oktatás a 21. században Székesfehérvár,

- Lükő István (1999): Környezet-társadalom-szakképzés Műszaki Könyvkiadó, Budapest,

- Lükő István (2004): Mi lesz veled szakoktató szak? Javaslat a szakmai pedagógusképzés lineáris szerkezeti rendszerére Szakoktatás, 2004/1. 20-22. o.,

- Lükő István (2005): Vertikális modularizáció egy szakképzés-pedagógiai kísérletben. V. ONK Budapest MTA PTB Program Tartalmi összefoglalók, Budapest,

- Lükő István (2007): Szakképzés-pedagógia Műszaki Kiadó, Budapest,

- Lükő István (2007): Szakképzési rendszerek, struktúrák, kvalifikációk nemzetközi összehasonlítása Nemzetközi összehasonlító elemzés a szakképzési rendszerek állapotáról, müködéséről és fejlesztéséröl,

- Lükő I. (2016): Műszaki-technikai kultúra és tudomány Kulturális örökségvédelem szak előadás PPT Pécs,

- Lükő István (2018): Nemzetközi kitekintés az első szakképzési törvény korszakáról Opus et Educatio 6. évfolyam 1. szám,

- MKIK GVI (2019/1): Automatizáció és innováció a magyar vállalkozások körében, Budapest,

- Molnár Gy. (2018): Hozzájárulás a digitális pedagógia jelenéhez és jövőjéhez. In: Szerk.: B.A.: MTA-BEM Nyitott tananyagfejlesztési Kutatócsoport Közlemények IV.,

- Molnár Gy.-Orosz, Beáta (2019): Digitális eszközök használatával támogatott korszerű módszertani, tartalmi, technológiai megoldási lehetőségek a szakképzésben, In: Juhász, Erika; 
Endrődy, Orsolya (szerk.) OKTATÁS-GAZDASÁG-TÁRSADALOM, Budapest, Magyarország, Debrecen, Magyarország : Debreceni Egyetem, Magyar Nevelés- és Oktatáskutatók Egyesülete (HERA), (2019) pp. 592-607. 13 o.,

- Molnár György (2016): Pillanatképek az IKT szakképzésben alkalmazható megoldásairól avagy kételyek és jó gyakorlatok az innovatív pedagógiai módszerek útján. EDU Szakképzés és Környezetpedagógiai elektronikus szakfolyóirat 6/2: 7-18. o.,

- Pagonyné M.M. (2018): A szakképzés tartalmi változása és megvalósítása 1993-tól napjainkig. Ppt. Budapest,

- Pálmay Z. (1999): A technológiai fejlődés sajátosságairól Inco, Budapest,

- Marc Prensky (2001): Digitális bennszülöttek - digitális bevándorlók. Digital Natives, Digital Immigrants. MCB Uni-versity Press,

- Setényi János (1996): Az OECD munkaerő-piaci elemzése In: Educatio 1996/1 145-174 o.,

- Simonics, István (2017): A szakmai tankönyvek helye és szerepe a felsőoktatásban In: Hülber, László; Tamásné, Fekete Adrienne (olvasószerkesztő) (szerk.) II. Oktatástervezési és Oktatásinformatikai Konferencia: absztraktkötet Eger, Magyarország: Líceum Kiadó, 59. o.,

- Simonics, István; Holik, Ildikó (2014): Információfeldolgozási technikák hatékonyságának vizsgálata a mentortanárok képzésében In: Tóth, Péter; Ősz, Rita; Várszegi, Ágnes (szerk.) Pedagógusképzés - személyiségformálás, értékközvetítés, értékteremtés: IV. Trefort Ágoston Szakmai Tanárképzési Konferencia tanulmánykötet Budapest, Magyarország: Óbudai Egyetem Trefort Ágoston Mérnökpedagógiai Központ, 403-416. o.,

- Simonics István (2016): A pedagógusképzés megújítása, Budapest: Typotop Kft., (Szakmai pedagógusképzés sorozat; 21.), (ISBN:978-615-80494-2-9)

- Simonics István (2017). Mérnöktanárok és mentortanárok IKT eszköz felhasználása, In: Mrázik Julianna (szerk.) HERA Évkönyv 2016: A tanulás új útjai. Budapest: Magyar Nevelés- és Oktatáskutatók Egyesülete (HERA), 2017. 298-315. o.,

- Uwe Leuterbach (1996): Internacionales Handbuch der Berufsbildung Nomos verlaggeselschaft Baden-Baden.

\section{Internetes források:}

- https://www.oktatas.hu/kepesitesek elismertetese/jogszabalyok

- http://www.econstats.com

- https://www.oecd-ilibrary.org

- http://ec.europa.eu/eurostat

- https://www.cia.gov/library/publications/the-world-factbook/rankorder/2085rank.html 